
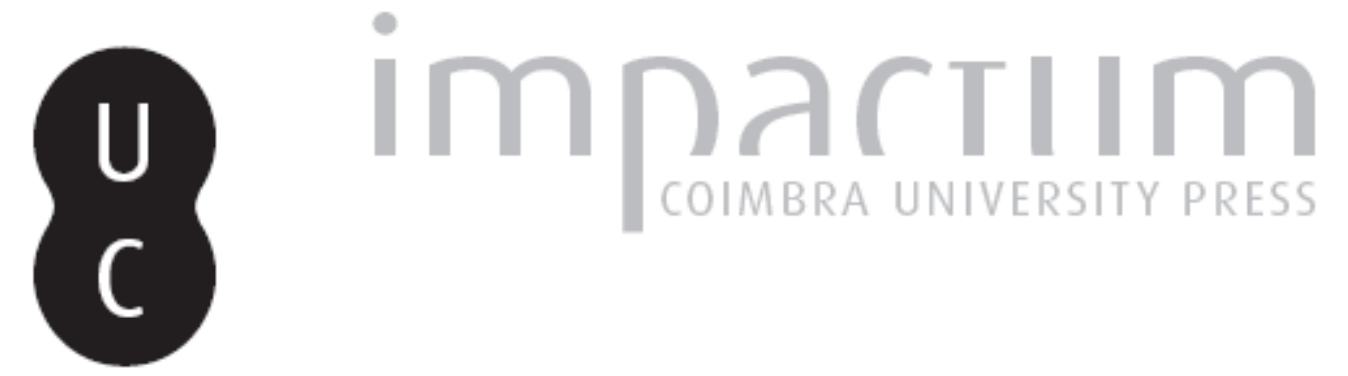

\title{
Os tumuli do Rochão (Castro Daire, Viseu)
}

Autor(es): $\quad$ Santos, André Tomás; Marques, João Nuno

Publicado por: Faculdade de Letras da Universidade de Coimbra

URL persistente:

URI:http://hdl.handle.net/10316.2/37744

DOI:

DOI:http://dx.doi.org/10.14195/1647-8657_46_2

Accessed : $\quad$ 26-Apr-2023 14:46:40

A navegação consulta e descarregamento dos títulos inseridos nas Bibliotecas Digitais UC Digitalis, UC Pombalina e UC Impactum, pressupõem a aceitação plena e sem reservas dos Termos e Condições de Uso destas Bibliotecas Digitais, disponíveis em https://digitalis.uc.pt/pt-pt/termos.

Conforme exposto nos referidos Termos e Condições de Uso, o descarregamento de títulos de acesso restrito requer uma licença válida de autorização devendo o utilizador aceder ao(s) documento(s) a partir de um endereço de IP da instituição detentora da supramencionada licença.

Ao utilizador é apenas permitido o descarregamento para uso pessoal, pelo que o emprego do(s) título(s) descarregado(s) para outro fim, designadamente comercial, carece de autorização do respetivo autor ou editor da obra.

Na medida em que todas as obras da UC Digitalis se encontram protegidas pelo Código do Direito de Autor e Direitos Conexos e demais legislação aplicável, toda a cópia, parcial ou total, deste documento, nos casos em que é legalmente admitida, deverá conter ou fazer-se acompanhar por este aviso.

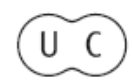




\section{CONIMBRIGA}

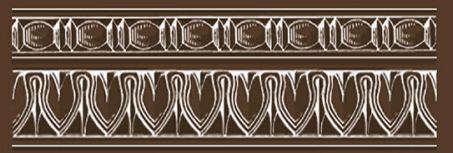

INSTITUTO DE ARQUEOLOGIA

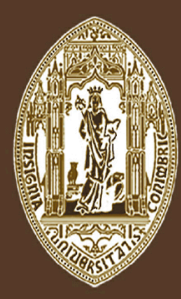

VOLUME XLVI - 2007

FACULDADE DE LETRAS UNIVERSIDADE DE COIMBRA 
ANDRÉ TOMÁs SANTOS

Centro de Estudos Pré-Históricos da Beira Alta

JoÃo NunO MARQues

Palimpsesto, Estudo e Preservação do Património Cultural, Lda.

geral@palimpsesto.pt

OS TUMULI DO ROCHÃO (CASTRO DAIRE, VISEU)

"Conimbriga" XLVI (2007) p. 27-51

Resumo: Publicam-se os resultados obtidos nas escavações arqueológicas dos monumentos I e II do Rochão (Castro Daire, Viseu). Estes sítios assemelham-se pelas suas características a vários outros conhecidos na região e que podemos datar entre o Bronze Médio e Final. Estas construções de pequenas dimensões e formas subcirculares, são pequenos montículos cobertos de pedras, destacando-se o quartzo, que lhes confere uma certa visibilidade. Não sendo exemplo único, estes monumentos revelam-nos um interessante caso de reutilização e de reconfiguração do espaço e do tempo.

ABSTRACT: The results obtained at the archaeological excavation of the monuments I and II at Rochão (Castro Daire, Viseu) are published here. Taking into account their characteristics, these sites are similar to many other sites known in the region and they can be included between the Middle and Late Bronze Age.

These small and nearly circular constructions are small hills covered with rocks, from which quartz stands out which gives these constructions a much better visibility.

Although these are not the only example, these monuments reveal an interesting case of re-use and reconfiguration of space and time. 
(Página deixada propositadamente em branco) 


\section{OS TUMULI DO ROCHÃO (CASTRO DAIRE, VISEU)}

\section{Introdução}

É objectivo deste texto apresentar os resultados dos trabalhos arqueológicos realizados na necrópole beiraltina do Rochão. Trata-se de dois tumuli muito baixos, semelhantes a outros que têm vindo a ser identificados e intervencionados na região e que cronologicamente se situarão num período que vai dos finais do Bronze Médio (Cruz et alii, 1998a) ao Bronze Final (v. g. Kalb e Höck, 1979; Kalb, 1994; Cruz e Vilaça, 1999; Vilaça e Cruz, 1999; Cruz et alii, 1998b; Vilaça et alii, 2000; Santos e Aveleira, 2001). Como se verá seguidamente, os monumentos que agora se apresentam têm particularidades próprias que contribuirão decerto para um melhor conhecimento deste fenómeno na área em apreço.

Os tumuli foram identificados no decurso do acompanhamento arqueológico do projecto "IP3 - SCUT Interior Norte - Lanço A: IP5 Castro Daire Sul" adjudicado pela Norinter - Construtora de Auto-estradas A.C.E à empresa Palimpsesto, Estudo e Preservação do Património Cultural, Lda. Os trabalhos foram dirigidos por Eduardo Porfírio e Hélio Reis que identificou os referidos monumentos.

Os monumentos encontravam-se algo mutilados, pelo que a sua identificação como mamoas não era certa. Assim, após visita ao local, optou-se por se proceder a sondagens prévias que viessem a demonstrar a origem antrópica do sítio. No final destes trabalhos, e vendo-se esta hipótese confirmada, procedeu-se então à escavação integral das construções tumulares de modo a permitir o normal prosseguimento da obra em curso.

Os trabalhos foram dirigidos pelos signatários, tendo ainda colaborado em diferentes fases: Lília Basílio, Susana Andreia Nunes, Ivone Canavilhas, Sofia Tereso, Nuno Silveira, Artur Serra, Miguel Serra, Alexandre Valinho, Eduardo Porfírio e Mauro Mendes (desenho de materiais). O apoio topográfico foi prestado pela Norinter - Construtora 
de Auto-estradas A.C.E. Ao longo de todo o processo contámos também com a inestimável ajuda de Domingos Jesus da Cruz, a quem agradecemos vivamente. Os trabalhos decorreram, de forma intermitente, entre os meses de Maio e Julho de 2003.

\section{Localização}

Administrativamente, a área onde se implantava a necrópole pertence à freguesia de Calde, concelho de Viseu, distrito de Viseu. Os tumuli encontram-se cartografados na Carta Militar de Portugal, escala 1: 25 000, folha 167. O monumento 1 encontra-se nas seguintes coordenadas Greenwich: $7^{\circ} 55^{\prime} 25^{\prime \prime} \mathrm{W}$; $40^{\circ} 47^{\prime} 33^{\prime \prime} \mathrm{N}$; altitude: 416 metros. O monumento 2 situava-se a cerca de $100 \mathrm{~m}$ para sul-sudeste, nas coordenadas Greenwich: $7^{\circ} 55^{\prime} 23$ ' W; 40 47' 26" N; altitude: 426 metros.

Os pequenos relevos situavam-se num pequeno esporão que se destacava na encosta norte da elevação de Calde, abatendo-se progressivamente sobre o vale da ribeira de Cabrum, desenvolvendo-se grosso modo na direcção sul - norte. Este esporão descia de forma "arritmada", facto que lhe oferecia um perfil em "escada", sendo que cada degrau corresponderia a uma chã. Os nossos monumentos situavam-se precisamente em duas destas pequenas plataformas, uma (onde se localizava o monumento 1) a norte da outra. A localização destes monumentos permitia uma visibilidade razoável para este, ainda mais substancial para oeste, mas sobretudo para norte, onde era bastante ampla, advindo esta situação do facto de nessa direção se encontrar a confluência de três importantes linhas de água regionais - da ribeira de Cabrum com a ribeira de Freixiosa e desta com o rio de Mel (Est. I - figs. 1 e 2).

Actualmente, estes terrenos eram apenas explorados como pinhal.

Geologicamente, encontramo-nos frente a granitos, que, como os de toda a região em volta, pertencem à orogenia hercínica. Com base em critérios petrográficos, de granulometria e composição, Schermerhorn definiu para a região 10 facies de cronologias diferentes (sendo a mais antiga a 1 e a mais recente a 10). As quatro primeiras são consideradas antigas (do Carbónico Médio), as restantes, recentes (do Pérmico Inferior - Antuniano) (Schermerhorn, 1980, 17). Com a excepção do granodiorito horneblendo-biotítico de Lamelas, todos os restantes apresentam composições mineralógicas semelhantes, sendo todos biotíticos com quantidades variáveis de moscovite (Schermerhorn, 1980, 17-18). 
O tipo IX é o que está presente na zona em estudo (granitos porfiróides, predominantemente biotíticos). Como em todos os granitos recentes, com excepção dos tipos V e VI, o feldspato potássico é dominante, encontrando-se em associação com aplitos, pegmatitos e mineralização de estanho e tungsténio. Todos são micáceos sem anfíbolos ou quaisquer outros minerais máficos (Schermerhorn, 1980, 18).

No seio da mancha granítica do tipo IX identificam-se três batólitos, sendo o que nos interessa o de Cota, que se caracteriza pelos seus grandes cristais de feldspato potássico porfiróide (megacristais) inseridos numa matriz grosseira onde os cristais apresentam uma média de tamanho entre 3 e $7 \mathrm{~mm}$, podendo, no entanto, atingir os $12 \mathrm{~mm}$. As placas de biotite apresentam dimensões que podem atingir os $4 \mathrm{~mm}$ de largura, e quantidades variáveis de moscovite (até os $5 \mathrm{~mm}$ de largura) e feldspatos de diferentes tamanhos. Sendo rochas magmáticas primárias, ocasionaram, por vezes, alterações metassomáticas por feldspatização potássica e outros processos nas zonas adjacentes de granitos mais antigos, sendo ainda responsáveis pela mineralização de estanho e tungsténio. Refira-se ainda que a sua meteorização coloca em grande evidência os cristais de feldspato, dando origem ao dito "dente de cavalo" (Schermerhorn, 1980, 21). A biotite é castanha. A moscovite é rara ou mesmo ausente, só aparecendo junto às litologias anteriores. A foliação dos megacristais é mais fraca que nos restantes granitos, podendo mesmo estar ausente. Observam-se ainda xenófilos e enxame de xenófilos. Os aplitos são muito raros. Ainda condicionada por este tipo de granito é a existência dos grandes blocos que pontuam a paisagem da zona, fruto da sua meteorização (Schermerhorn, 1980, 23).

Geomorfologicamente, encontramo-nos numa área "movimentada e complexa", situada no interflúvio Paiva - Vouga. Esta topografia particular deve-se, por um lado, às diferentes litologias presentes na área e a fenómenos tectónicos (visíveis, por exemplo, no curso da ribeira de Freixiosa referida acima). Embora estes últimos e a pouca resistência dos granitos (em particular do tipo IX) não tenham permitido uma boa conservação de antigos níveis de aplanamento, é ainda possível distinguirem-se, pelo menos, três: um primeiro, situado a norte, nordeste e leste do interflúvio e que corresponde a pequenos retalhos da superfície fundamental da serra da Nave (entre os 850 e os 900 metros); um segundo, denominado «superfície inferior», situado grosso modo entre os 700 e os $750 \mathrm{~m}$, particularmente entre Pendilhe e S. Joaninho, mas conservado também em alguns pontos de Castro Daire, S. Pedro do Sul e Viseu, 
onde devemos incluir o topo da elevação onde se situa Calde (a sul desta terra). Na zona onde se encontra esta povoação encontramos um terceiro nível de aplanamento, contemporâneo dos vales do Paiva e do Vouga. A partir desta platitude para oeste até ao rio de Mel, e para norte, até à ribeira de Cabrum, o relevo desce até cotas entre os $300 \mathrm{e}$ os $320 \mathrm{~m}$. A este progressivo declínio não deve ser estranho o substrato rochoso de que falámos atrás, que é o mais facilmente erosionável (Ferreira, 1978, 92-105, em particular 103-105).

A nível da fitossociologia, a serra do Caramulo deverá integrar-se no superdistrito Miniense Litoral, subsector miniense, sector galaico-português, subprovíncia Galaico - Asturiana, província Cântabro-Atlântica, superprovíncia Atlântica, sub-região Atlântica Médio Europeia, região eurosiberiana (Costa et alii, 1998, 14).

Do ponto de vista do clima, encontramo-nos numa zona de transição entre um clima marcadamente atlântico e um de matiz mais continental. Trata-se de regiões ainda largamente abertas às massas de ar marítimas, se bem que de forma indirecta. Aqui, os dias ou períodos atlânticos alternam com os de carácter mais continental. É normal a existência de persistentes nevoeiros nas terras baixas. $\mathrm{O}$ ar carregado de humidade que vem de oeste e após atravessar as barreiras montanhosas que se interpõem pode arrefecer muito durante as noites. Contudo, pode afirmar-se que até à bacia de Celorico o clima continua muito húmido e com amplitudes térmicas baixas (Daveau, 1997, 454).

Até ao momento, as actividades mais representativas da região são a agricultura, a criação de gado e alguma indústria incipiente, advinda da proximidade com Viseu.

\section{A pré-história regional}

Os primeiros vestígios antrópicos ${ }^{1}$ da região correspondem aos monumentos megalíticos, estruturas em pedra de proporções monumentais que devem ser integráveis no Neolítico regional (finais do V e decorrer do IV milénio AC, com especial incidência na sua primeira metade) (Cruz, 1995)²;

1 Deve, no entanto, ter-se em conta que no corte palinológico efectuado em Canedotes (López et alii, 2000), há sinais da possível antropização do território em tempos mesolíticos, nomeadamente através da utilização do fogo.

2 A quantidade de monumentos deste tipo (e de outros) na região pode ser aferida pela leitura do inventário da tese de doutoramento de Domingos Jesus da Cruz (2001). 
a partir de finais do IV/inícios do III milénio começam a pontuar a paisagem monumentos de menores dimensões que no Bronze Final atingem o máximo de discrição (Cruz, 1998, 160-163); exemplo paradigmático deste tipo de sítios é a necrópole do Pousadão (Cruz et alii, 2000), cujo local de implantação se avista daqui, ou alguns dos monumentos que compõem a necrópole da Fonte da Malga, também ela não muito distante (Kalb e Höck, 1979).

Quanto a sítios de habitat, a única estação das imediações que parece apontar para cronologias anteriores ao Bronze Final corresponde ao Outeiro da Maga que aparentemente terá sido ocupado durante o Calcolítico (Cortez, 1951, 164-165, 181). Este local terá sido ainda habitado durante o Bronze Final e a Idade do Ferro (Loureiro et alii, 2006, 109). Do Bronze Final, deve ainda ser referido o sítio de Canedotes (Canha, 1999; Canha, 2002), enquanto que da I Idade do Ferro é sítio paradigmático pela sistemacidade dos trabalhos aí desenvolvidos o Castro de Vila Cova-à-Coelheira (Valinho e Loureiro, 1999; Loureiro e Valinho, 2000; Loureiro, 2003).

Finalmente, há ainda que relevar o importante fenómeno da arte rupestre ao ar livre na região (Silva, 1978; Silva, 1985). Ocupando diacronias que poderão ir dos finais do Neolítico à Idade do Ferro (Santos, 2003, 121-132), conhecem-se variadíssimos exemplos na região, devendo destacar-se pela proximidade a estação da Pedra dos Pratos (Rodrigues et alii, 1989; Santos, 2000). Feito este breve resumo da pré-história da região, retornemos aos monumentos que são objecto de análise deste texto, não sem antes caracterizarmos a metodologia e estratégias adoptadas durante a intervenção arqueológica.

\section{Metodologia e descrição dos trabalhos}

A metodologia utilizada foi a comummente adoptada nas escavações deste género de monumentos, com as devidas adaptações advindas do tipo de intervenção que se estava a efectuar.

Assim, numa primeira fase, apenas foram abertas sondagens em ambos os monumentos que pudessem confirmar a origem antrópica das estruturas. Começou-se por remover a vegetação na área a intervencionar. No sítio 1 foi implantada uma quadriculagem de 10 metros por 14 metros. O eixo dos Y's foi traçado paralelamente ao eixo do monumento ( $40^{\circ}$ desviado para este). Dividiu-se a quadriculagem em quadra- 
dos de 2 metros de lado. Ao eixo dos X's atribuíram-se letras (B', A', A e B) e ao dos Y's números (de 1 a 7). Foram decapados os quadrados A4, A5, a metade este dos quadrados A'5, A'4, A'3 e A'2 e a metade oeste dos quadrados $\mathrm{A} 2$ e $\mathrm{A} 3$, perfazendo uma área de $20 \mathrm{~m}^{2}$. Antes de qualquer remoção de terras, procedeu-se ao levantamento topográfico do sítio e respectivo registo fotográfico. Todas as estruturas colocadas a descoberto foram também desenhadas em papel milimétrico à escala de 1: 20.

No monumento 2 seguiu-se a mesma estratégia. A quadriculagem deste ocupava uma área de $8 \mathrm{~m}$ por $16 \mathrm{~m}$. O eixo dos y's foi implantado paralelamente ao eixo maior da disposição das pedras (sentido sul-norte). Ao eixo dos X's foram atribuídas letras (B', A', A e B) e ao dos y's números (de 1 a 8 ).

Ambos os monumentos foram georeferenciados na rede geodésica nacional, trabalho executado por um topógrafo gentilmente cedido pela Norinter, entidade a quem, por este meio, agradecemos.

Logo após o primeiro nível de pedras dos tumuli terem sido colocados à vista, e tendo-se verificado o inegável interesse arqueológico dos monumentos, prolongou-se a decapagem para a área quadriculada. Os monumentos foram escavados manualmente, sendo qualquer alteração arquitectónica na massa de pedras que os constituíam registada graficamente à escala 1: 20 e por fotografia (cor e diapositivo). Em ambos os monumentos conservaram-se testemunhos de trinta centímetros que permitissem o registo da estratigrafia do monumento. Assim, em ambos os monumentos foram desenhados dois perfis perpendiculares entre si.

Todo o espólio recolhido foi localizado tridimensionalmente, encontrando-se a sua proveniência indicada no inventário dos materiais.

Em gabinete, todos os desenhos foram tintados (por Lília Basílio) e reduzidos para a escala em que agora se apresentam. Os levantamentos topográficos foram alvo de tratamento informático com o programa SURFER 8. Os materiais recolhidos foram lavados, marcados e inventariados, tendo sido desenhados os que se entenderam como relevantes.

Como se verá seguidamente, foi identificada no monumento 2 uma laje insculturada. Esta foi recolhida, tendo o seu decalque sido efectuado em gabinete. Utilizou-se para isso plástico de polivinilo de transparência e espessura adequadas. O limite da laje foi desenhado com uma caneta vermelha de ponta $\mathrm{M}$. As fracturas e acidentes naturais da 
pedra foram representados com caneta da mesma cor, ponta F. Os sulcos foram representados a negro, em toda a sua extensão.

Este decalque foi passado para papel de engenheiro à escala natural, utilizando-se para isso as seguintes canetas: caneta negra de ponta 1 para o limite da pedra, pontilhado a caneta negra de ponta 0,5 para as fracturas e acidentes naturais da rocha, sendo os sulcos representados na mesma cor ocupando toda a largura dos mesmos.

A laje foi fotografada em gabinete com diferentes tipos de película (cor, preto e branco e diapositivo), utilizando-se a luz rasante proveniente de dois focos, colocados em posições diversas.

\section{Descrição dos monumentos e estratigrafia}

\subsection{Monumento 1}

O monumento 1 encontrava-se, como se disse atrás, localizado no limite de uma pequena chã com ampla visibilidade para norte. Na sua construção teve-se em conta o próprio desnível da elevação em que se encontrava. Assim, o seu lado norte e, de forma mais impressiva, o sector oeste, tinha uma monumentalidade que o os restantes lados não revelavam. Esta monumentalidade poderá ter, no entanto, que ver com o declive do terreno que poderá ter feito com que escorressem os materiais mais leves naquelas direcções.

Apresentaria uma planta genericamente circular com cerca de 7 metros de comprimento. O tumulus era constituído apenas por elementos pétreos, destacando-se de sobremaneira o quartzo, pese o facto de também se identificarem alguns granitos. A sul, adossado ao monumento, ou mesmo fazendo parte dele, identificou-se uma estrutura circular com cerca de 3 metros de diâmetro, também constituída essencialmente por pedras. Refira-se, no entanto, que ao contrário do "monumento central", este se encontrava melhor preservado a este. Deve-se este facto à forte pendente do terreno para oeste, o que terá provocado o deslize dos elementos pétreos para esse lado. Como elementos constituintes, também aqui se verifica a predominância do quartzo.

A separar as duas estruturas atrás referidas, identificou-se um alinhamento de sentido este - oeste constituído por grandes lajes de granito. 
Sob a primeira camada de pedras do cairn identificou-se um "lastro" constituído por grandes lajes de granito que pareciam formar uma planta subcircular, mutilada a este. No seu interior ou sob ela não se encontrou qualquer tipo de estrutura ou vestígio antrópico.

No interior da estrutura secundária também não se identificou nada de relevante.

A estratigrafia era muito simples. Foi identificada uma primeira camada de terras negras de grão médio a fino, muito humosas e soltas e com abundantes raízes. Cobria as pedras do cairn. Uma segunda camada, sobre aquela, e entre as pedras que formavam o tumulus, diferenciava-se da anterior pela sua cor mais castanha e pela sua maior compacticidade. Trata-se de terras que escorreram a partir da superfície. Sob o monumento foi identificada uma terceira camada de terras castanhas de grão médio a fino, muito compactas. Apenas aqui se exumaram materiais arqueológicos de cronologia pré-histórica.

\subsection{Monumento 2}

Este monumento situava-se a cerca de 100 metros para sul-sudeste do anteriormente descrito. De igual modo, localizava-se no topo de uma elevação semelhante a um pequeno esporão. O domínio visual deste tumulus era, portanto, muito semelhante ao do anterior. Este monumento apresentava a sua cobertura pétrea mais mutilada que a do número 1, nomeadamente na sua periferia. Este facto devia-se, essencialmente, às árvores que aqui se encontravam.

Também aqui se verificava que na massa de pedras de aspecto caótico se poderiam distinguir duas realidades arquitectónicas. Assim, a norte configurava-se um tumulus genericamente circular constituído essencialmente por pedras de variado tamanho, com relevo para o quartzo branco, embora também se identificassem, aqui e ali, alguns elementos de granito de médio e grande calibre. Apresentava um diâmetro de cerca de 4,5 metros. A sua altura não ultrapassava os 0,5 metros. A sul identificava-se um aglomerado de blocos de médio e grande calibre, muito soltos, que configuravam uma planta sub-rectangular com 4 x 3 metros no sentido norte-sul e este-oeste, respectivamente. As suas características apontavam para que se tratasse de um "merouço", montículo de pedras soltas resultante da limpeza dos campos em volta. 
No cairn, após a remoção da primeira camada de pedras, identificou-se uma área central onde se destacavam os elementos de granito de médio e grande calibre. A escavação desta área revelou uma estrutura de forma genericamente circular delimitada por lajes graníticas. No seu interior não se exumou, contudo, qualquer material arqueológico.

$\mathrm{Na}$ estrutura mais a sul, identificou-se sobre as pedras mais soltas um alinhamento de grandes lajes graníticas que deveriam corresponder a parte do limite exterior do cairn. A cerca de 0,40 m desta estrutura foi localizada uma laje granítica fincada no solo, insculturada, e que descreveremos mais à frente. Adossadas àquele alinhamento encontrava-se um aglomerado de pedras de pequeno e médio calibre que se justapunham de forma mais compacta. Sob esta massa de pedras foi identificada uma estrutura de contorno semicircular já assente na camada de terras sobre a qual assentaria o cairn. Nesta última camada foi ainda identificada uma fossa que apenas continha algumas pedras e dois fragmentos cerâmicos.

Estratigraficamente, o arco de círculo é anterior ao cairn. E no tempo médio? Corresponderão a diferentes realidades culturais? $\mathrm{Na}$ verdade, com base no monumento 1 podemos interpretar esta estrutura como os restos de algo semelhante ao "anexo" que existia no outro monumento escavado. Contudo, neste caso as pedras mais profundas que a constituiriam perfuravam a camada abaixo. Para reforçar esta hipótese, reparemos que o limite norte da estrutura termina no alinhamento de lajes graníticas referido acima (e que se situa já na camada do monumento). Por outro lado, a construção do cairn pode ter-se dado quando a estrutura sobre a qual nos debruçamos agora se encontrava ainda à vista, tendo sido "condenada" nessa altura ou imediatamente antes. Ambas as hipóteses até aqui nos parecem razoáveis. Contudo, não devemos esquecer a existência comprovada de uma ocupação anterior do sítio como se pode atestar pela presença de materiais arqueológicos na camada subjacente ao monumento e pela presença da fossa atrás referida. Devemos então pressupor que a existência de estruturas positivas relacionadas com esta ocupação torna-se altamente relevante. Ora, esta evidência implica a necessidade de procurar razões para a "condenação" desses vestígios e consequente alteração das actividades que aqui decorreram, assim como das possíveis relações com o outro tumulus da necrópole. Contudo, a este assunto voltaremos mais tarde.

Quanto à estratigrafia, ela é, como a do monumento anterior, muito simples. Assim, em cima foi identificada uma primeira camada 
(camada 1) de terras castanhas escuras muito pulverulentas, com abundantes raízes, correspondente à camada humosa. Sob esta e entre as pedras que constituíam as estruturas encontrava-se uma terra (camada 2) de cor castanha amarelada, constituída por grãos de pequeno e médio calibre, pouco compacta, ainda com algumas raízes. Registe-se aqui a ocorrência de material arqueológico, nomeadamente um "peso de pesca" feito a partir de um seixo com um entalhe em cada lado. Abaixo, identificou-se a camada 3, caracterizada pela sua cor alaranjada, grão médio e uma compacticidade apreciável; ocorre aqui material arqueológico, nomeadamente ceramológico. Nela foi identificado o arco de círculo e a fossa atrás referidos. Abaixo, identificou-se ainda uma quarta camada composta pelos elementos resultantes da desagregação do substrato geológico. Era estéril, do ponto de vista arqueológico.

\section{A laje insculturada}

Encontrava-se no quadrado A'2 do monumento 2, fincada no solo e paralela, como já se referiu, ao alinhamento de lajes de maiores dimensões que pareciam definir o limite do cairn situado mais a sul.

Trata-se de uma peça em granito porfiróide, de grão médio a grosseiro, destacando-se os elementos de quartzo e feldspato de grande tamanho (corresponde ao granito da região - a facies IX de Schermerhorn referida acima). Apresenta uma pátina branca com tendência para o amarelo, à excepção do seu terço superior, em que é acinzentada escura, facto que se explica pela maior exposição desta parte aos elementos atmosféricos. Apresenta vários lascamentos de importância variável, mais uma vez destacando-se os do seu terço superior. A base apresenta-se fracturada. Dada a posição em que se encontrava a laje, podemos ser levados a inferir que será uma fractura antiga, correspondente a uma fase prévia à gravação da pedra, explicando-se a "frescura" daquela pelo facto de se encontrar enterrada. No entanto, como se verá adiante, temos pistas que podem apontar noutros sentidos interpretativos que deverão ser tidas em conta.

A laje tem uma forma sub-rectangular. Apenas a base apresenta uma forma subtriangular. A secção é também sub-rectangular. As dimensões são as seguintes: altura máxima - 33,4 cm; largura máxima - 31,5 cm; espessura máxima: 5,9 cm. 
Os sulcos foram executados por picotagem, provavelmente indirecta dada a complexidade da composição que exigiria alguma minúcia. Os negativos apresentam uma forma subcircular e aberta, sendo pouco profundos, o que nos leva a inferir que a gravação foi feita com percutor lítico de ponta romboidal. A largura dos sulcos varia entre os 0,2 e os $0,9 \mathrm{~cm}$. A profundidade dos mesmos, entre os 0,1 e os $0,2 \mathrm{~cm}$.

A figura representada é uma composição reticulada que arranca da base da peça e que eventualmente terminaria no seu topo, dados os vestígios de sulcos que aí encontramos. O reticulado não parece prolongar-se para os lados da laje. Apresenta cinco sulcos verticais descontínuos e vestígios do que parece ser um sexto à esquerda da composição que chegou até nós. Verifica-se ainda a existência de quatro sulcos horizontais. Entre o primeiro sulco e o segundo a contar do topo, verifica-se a existência de três quadrados. Entre o segundo e o terceiro, quatro quadrados. Entre o terceiro e o quatro, outros quatro. Por sua vez, o espaço definido entre o último sulco e a base da laje encontra-se dividido em dois (Est. VI - fig. 3).

Esta laje denota evidentes paralelismos, tanto na sua forma como na composição gravada, com outras que, de há uns anos a esta parte, têm vindo a ser identificadas em contextos que vão do Bronze Final até à segunda Idade do Ferro (alguns destes, datados pelo ${ }^{14} \mathrm{C}$ ) na Beira Alta.

Uma laje deste género foi identificada no monumento 3 de Casinha Derribada (Viseu), aqui funcionando como tampa (Cruz et alii, 1998, 51; Fot. 2). Uma outra foi identificada no sítio de habitat de Canedotes (Vila Nova de Paiva) (Canha, 1999, 287; Fig. 5). Um conjunto importante corresponde às lajes que definem o perímetro do monumento da Travessa da Lameira de Lobos (Castro Daire) (Cruz, 2001, 331). Perto deste sítio, foi identificado um tumulus, em cujas imediações foi também localizada uma laje semelhante (Cadouço, Castro Daire) (Cruz, 2001, 332).

A maior parte das lajes referidas tem como base das suas composições reticulados semelhantes ao da laje do monumento 2 do Rochão. Na verdade, apenas algumas das lajes da Travessa da Lameira de Lobos não se encontram insculturadas com composições com base nesta figura, mas em semicírculos. Contudo, este é, até ao momento, o único sítio onde foi identificada mais que uma laje.

Pese embora a relativa homogeneidade gráfica dos exemplos referidos, diferenças existem que devem ser relevadas e que poderão contribuir para uma melhor abordagem à peça que agora estudamos. 
A primeira é, obviamente, a cronológica. As três primeiras estações encontram-se datadas pelo ${ }^{14} \mathrm{C}$. As datas do monumento 3 de Casinha Derribada e de Canedotes permitem-nos situar estes sítios no Bronze Final. No entanto, recentes datações do monumento da Travessa da Lameira de Lobos, situam aquele monumento na segunda Idade do Ferro. Para já, será de valorizar, por um lado a existência de uma tradição que se prolongou ao longo de um tempo razoável, e por outro, uma certa coerência geográfica, que nos pode levar por caminhos que este texto não pretende desbravar. No caso concreto de que nos ocupamos agora, será de, pelo menos provisoriamente, aceitarmos uma cronologia do Bronze Final. Suportamos esta premissa com base em três observações que têm o valor que têm: as lajes de Travessa de Lameira de Lobos não se restringem a reticulados; Travessa da Lameira de Lobos não tem tumulus, ao contrário dos monumentos do Rochão e de todos os outros sob tumuli datados pelo ${ }^{14} \mathrm{C}$, existentes na região; os materiais encontrados nesta escavação, embora parcos, inserem-se bem no que se conhece do Bronze Final da região.

A segunda tem que ver com os contextos em que estas peças aparecem. Apenas um dos exemplares não se exumou num contexto claramente funerário - o de Canedotes. Aqui foi exumada numa área de elevada concentração de elementos pétreos. O investigador responsável pelo estudo do sítio considera que aqui estaríamos perante uma área funcional relacionada com o armazenamento. Não descarta, no entanto, a hipótese daquela acumulação de pedras constituir uma estrutura de elevado valor simbólico relacionado com a delimitação de um espaço (Canha, 1999, 290). A corroborar isto refere o aparecimento de um espeto articulado nas imediações (Vilaça e Cruz, 1995). Seja como for, não deixa de existir um certo paralelismo entre esta estrutura e os monumentos funerários coevos que existem na região. Mesmo que não nos encontremos perante um monumento desse género, julgamos que será de valorizar a semelhança evidente entre esta estrutura e aqueles.

A terceira diferença tem que ver com o campo operativo das lajes. Assim, em Travessa da Lameira de Lobos apenas os dois terços superiores das pedras se encontravam gravados. Sabemos, neste caso, que as lajes se encontravam fincadas. Deste modo, a parte enterrada não se apresentavam decorada. No caso do monumento 3 de Casinha Derribada, o campo gravado corresponde a toda a face historiada. Uma vez 
que toda essa face seria visível (pelo menos, até à sua "condenação" precedida por uma pequena fogueira acendida sobre a laje) não haveria necessidade de "condensar" a área a gravar. O exemplar de Canedotes encontrava-se, como os de Travessa da Lameira de Lobos, gravado apenas nos seus dois terços superiores. Embora tivesse sido exumado na horizontal, o seu contexto permite-nos supor que originalmente se encontraria posicionado na vertical. Por outro lado, a este nível, a laje de Cadouço aproxima-se mais da do monumento de Casinha Derribada 3. Na verdade, também a gravação da pedra daquele sítio ocupa toda a face anversa da peça. Embora não seja claro, julgamos que em Cadouço, a laje se encontraria também in situ, na posição horizontal. $\mathrm{Na}$ verdade, algumas pequenas pedras em seu torno pareciam estar, de algum modo, estruturadas. Dados os exemplos referidos, somos forçados a admitir que não é a pedra que importa gravar mas a parte visível desta.

Contudo, o exemplar do monumento 2 do Rochão encontra-se gravado na parte enterrada. Mais, a sua base encontra-se fracturada. Ora, este facto levanta interessantes questões. Ao contrário dos exemplos referidos acima, a tónica aqui não se encontra na mensagem veiculada pela composição, na medida em que parte desta não se encontra visível, mas nos potenciais significados da laje em si. Ou seja, aqui a pedra não é um mero canal mas a mensagem em si. Sem dúvida, no entanto, que o facto de se encontrar gravada é o que a torna especial. Tentemos abrir mais o nosso raciocínio...

Uma característica que partilham estas peças é a sua portabilidade. $\mathrm{Na}$ verdade, se excluirmos alguns exemplares da Travessa da Lameira de Lobos e do monumento 3 da Casinha Derribada, que exigiriam, pelo menos, duas pessoas para o seu transporte, todas as outras são facilmente manuseadas por uma pessoa só.

Dada esta característica, julgamos que será de toda a conveniência para uma correcta interpretação das mesmas e do exemplar do Rochão em particular, ter sempre em conta esta "portabilidade". Ora, esta característica particular pode levar-nos por vias interpretativas que julgamos serem de extrema relevância para a compreensão destas peças. Na verdade, ao aceitarmos que estas "estelas" devem ser encaradas como sendo portadoras de uma certa mobilidade devemos ter em conta, por um lado, a pertinência destes elementos na construção de cenários e, por outro, a ideia de que as criações humanas, tal como os próprios homens e mulheres, têm uma histó- 
ria própria, contêm em si uma genealogia e que a sua manipulação tem em conta este aspecto.

O conceito de cenário é, julgamos, altamente pertinente. Como cenário, encaramos um espaço físico onde se realizam determinadas actividades humanas, sendo composto por elementos fixos, semi-fixos e móveis que estruturam essas mesmas actividades (Rapaport, 1994, 461-462). Os elementos fixos correspondem grosso modo aos elementos arquitectónicos e alterações antrópicas mais perenes (como por exemplo, menires ou estações de arte rupestre, no caso da arqueologia). No extremo oposto, encontramos os elementos não-fixos que deverão ser considerados como os mais efémeros, os que apenas participam em actividades bem definidas no tempo (as pessoas ou os artefactos). Entre estes dois extremos, devemos colocar os elementos semi-fixos. Se não é grande novidade que a arquitectura tem um papel estruturante nas vivências das populações e, em última instância, na ideia que têm de si (v. g. Bourdieu, 2002, 37-55), será igualmente de ter em conta que também os artefactos possuem uma potencialidade política, na medida em que podem intervir no tecido social. Esta intervenção é manifesta não só no plano da criação e reforço de identidades (v. g. Valera, 2000, 156), mas também no de dar coesão à cosmogonia de uma comunidade, uma vez que a sua fácil deslocação permite a utilização das mesmas peças (ou semelhantes) em diferentes contextos que assim se vêem interligados e consequentemente fundidos num mesmo discurso social (v.g. Thomas, 1996, 78-82, 159-164; Tilley, 1999, 75-76). Os elementos semi-fixos se, por um lado, se apresentam como algo menos efémero, por outro, também têm uma certa facilidade em serem utilizados em diversos contextos. É esta ubiquidade que os torna tão importantes e pertinentes. Reparemos que é através destes elementos semi-fixos que uma praça se transforma numa sala de concertos ou uma rua num campo de futebol ou num mercado... São preponderantes na criação de contextos.

Ora, as características destas lajes - a saber, a sua relativa portabilidade, o seu aparecimento em diversos contextos, e no nosso caso particular, a possibilidade deste exemplar não se encontrar já no contexto de referência do seu criador - permitem-nos encará-las como elementos semi-fixos.

Mas porque dizemos nós que a peça não se encontra no contexto de referência do seu autor? Na criação de uma obra, o seu autor tem que ter em conta, entre outras coisas, o para quê da peça. Ora, é justa- 
mente a concretização deste para quê que designamos como referência, sendo que a peça deverá conformar-se a ele ${ }^{3}$. Ao afirmarmos que a peça não se encontra no contexto de referência do seu criador, estamos a assumir, portanto, que ela não se conforma ao contexto sobre o qual nos debruçamos de momento. E porque não se conforma? Como vimos atrás, nos restantes exemplares da região o campo operativo destas lajes é condicionado pela sua disposição. Quando a laje se encontra na horizontal, o campo operativo coincide com a própria peça; se se dispõe na vertical, a parte historiada é apenas a que fica visível. No caso que agora nos ocupa, a peça encontra-se, como referimos, na vertical, situando-se, no entanto, parte da composição enterrada. Frente a isto, podem colocar-se, entre outras, duas hipóteses que julgamos mais pertinentes: ou o inscultor tinha noção que parte da sua obra seria deliberadamente escondida (por razões rituais, por exemplo) ou a peça se destinaria a outro contexto em que seria disposta na vertical. No caso da primeira hipótese a peça conformar-se-ia à sua referência e no caso da segunda não. É evidente, a partir da leitura deste texto, que nos inclinamos para a segunda hipótese, evidência essa que necessita de ser fundamentada. E essa fundamentação prende-se essencialmente com uma questão de economia interpretativa (Eco, 1990, 96-112). Se nos outros exemplares referidos, dada situação se passa, procurar neste caso uma explicação que passe por cima desses casos implicaria um grande dispêndio interpretativo. Consequentemente, há que assumir que antes desta laje ser colocada no sítio onde foi recolhida, encontrava-se algures na posição horizontal.

$\mathrm{Na}$ medida em que se toda a composição não se encontra visível, existiu, no entanto, a preocupação de mostrar parte das gravuras, somos forçados a admitir, como dissemos atrás, que se a composição deixou de ser relevante, o facto da laje se encontrar gravada é claramente valorizado. Funcionou como um elemento semi-fixo na estruturação de determinado cenário. Mas como?

Como muitos autores têm vindo a dizer desde, há alguns anos, não só as pessoas têm uma genealogia, as coisas também as têm, nomeadamente a cultura material (v. g. Thomas, 1996, em particular 78-82). Ao abordarmos uma peça devemos ter em conta os seus contextos de produção, de utilizações e de deposições, em suma, a sua história. Um dado elemento da cultura material não é apenas a sua presença física,

3 Sobre estes aspectos consultar Heidegger, 1998, 97-103. 
mas a história de que é portador. Na verdade, como refere Heidegger, é no interagir quotidiano com as coisas ${ }^{4}$ que descobrimos o Mundo. Ao lidarmos com elas não as descobrimos como meras existências físicas ${ }^{5}$, mas como um plexo de referências que nos remetem para o Mundo (Heidegger, 1998, 86-90). Ora, se essas coisas são "deslocáveis”, não são só elas que se movem, mas de igual modo, os seus plexos de referência, onde devemos incluir as suas histórias.

A peça que encontramos no Rochão não é apenas uma laje gravada mas também o conjunto de referências que traz consigo, onde devemos incluir os seus contextos anteriores de utilização ou deposição, na nossa perspectiva não muito distantes do que se nos deparou na escavação ${ }^{6}$. Neste sentido, ganha particular relevância a ocupação anterior atestada no monumento 2. Se a laje proveio desse momento, então, de algum modo, ela continua visível no contexto a que nos referimos agora.

\section{Espólio}

Ao observarmos os quadros que expõem o inventário dos materiais recolhidos, o primeiro dado que salta à vista é uma clara discrepância na distribuição daqueles. Na verdade, no monumento 1 apenas há evidência segura da existência de um recipiente pré-histórico (composto pelos fragmentos 4, 5 e 6 que, embora não colem entre si, apresentam as mesmíssimas características), uma vez que os fragmentos 1,2 e 3 fazem parte da mesma peça já de cronologia histórica. Refira-se que, neste monumento, os materiais mais antigos recolheram-se na camada sob o tumulus. No entanto, a sua quantidade não nos permite supor a existência de uma ocupação anterior. Interpretamos, consequentemente, a sua ocorrência como perdas fortuitas durante a construção da mamoa.

No monumento 2 foi exumado espólio lítico e cerâmico. A nível do primeiro, no estrato mais antigo (camada 3) apenas foram recolhidos dois seixos que não apresentam qualquer vestígio de utilização. Os restantes elementos apareceram entre as pedras que constituíam o monumento (camada 2). Destes, três correspondem a seixos, sendo que ape-

4 Os utensílios à mão, na sua terminologia.

5 Ou seres ante os olhos.

6 Se admitirmos que tanto estas lajes como este tipo de monumentos são inseríveis no Bronze Final. 
nas um apresenta lascamentos que, no entanto, podem ser acidentais. Encontrou-se ainda um peso sobre seixo (Est. VI - fig. 2) e um percutor. A presença de pesos sobre seixos não é comum em contextos tumulares, mas encontra-se bem representada em contextos habitacionais do Bronze Final na Beira Alta (Canha, 2002, 245) e Interior (Vilaça, 1995, 318). O mesmo se pode dizer quanto a machados polidos (Canha, 2002, 248; Vilaça, 1995, 317). Contudo, são materiais que aparecem ao longo de um amplo espectro temporal, não tendo por isso um valor muito acentuado enquanto indicadores cronológicos precisos.

A nível de cerâmica, à superfície recolheram-se dois fragmentos. Um é histórico, o outro é demasiado informe para se dizer qualquer coisa. Na camada 1 recolheram-se dois elementos de cronologia histórica e três que interpretamos como pré-históricos. Dois destes apresentam pastas cinzentas, o outro castanha. Todas as superfícies são alisadas e castanhas. Os elementos não plásticos são de grão fino e médio, distribuindo-se uniformemente. Um destes exemplares trata-se de um bordo direito com o lábio biselado, outro é um bojo com arranque para o fundo que, contudo, é incaracterizável.

Na camada 2 foram inventariados 16 fragmentos (strictu sensum foram 18, mas pelo menos 3 são da mesma peça). Ao nível dos desengordurantes predominam os fragmentos cujos elementos não plásticos são de pequeno e médio calibre dispersos de forma homogénea. Existe um caso em que apenas se identificam grãos de baixo calibre, dois casos em que estes são de médio e grande calibre e um caso em que a par de grãos de pequeno e médio calibre distribuídos de forma homogénea, encontram-se outros de granulometria grosseira dispersos de forma pouco uniforme. As superfícies são maioritariamente lisas. Existem dois casos de polimento em ambas as faces e um caso em que esta técnica só é perceptível no exterior. Quatro exemplares apresentam as superfícies rugosas e um cujas superfícies se encontram muito erodidas.

Da camada 3 foram inventariados 13 elementos (a totalidade é de 17, mas em dois casos existe colagem de dois fragmentos e num outro de três fragmentos). Como na camada anterior, o desengordurante é composto por elementos não plásticos de pequeno e médio calibre, distribuídos de forma uniforme. Como excepções, temos três casos em que apenas se identificam grãos de pequeno calibre, um outro em que a granulometria é de pequeno e médio calibre dispersos de forma pouco homogénea, um em que estes elementos são de pequeno, médio e grande calibre dispersos homogeneamente e, finalmente, um caso seme- 
lhante em que os grãos de maior dimensão se encontram espalhados de forma irregular. Ao nível do tratamento de superfícies encontram-se algumas diferenças em relação à camada anterior. Assim, a técnica predominante é o polimento (5 exemplares); o alisamento encontra-se representado por um exemplar; um fragmento apresenta as superfícies rugosas e dois têm as faces muito erodidas; quatro apresentam o exterior polido e o interior alisado; num dos exemplares erodidos vislumbram-se vestígios de polimento no exterior. Quanto às cores das superfícies a que predomina é o bege (6 exemplares), seguido do castanho (4 exemplares) e do cinzento (3 exemplares); um fragmento tem as superfícies cinzentas e o núcleo castanho; dois têm as superfícies castanhas e o núcleo cinzento. Em relação a morfologias identificadas, contam-se dois bordos ligeiramente extrovertidos com os lábios boleados. Num destes fragmentos observa-se ainda um colo subcilíndrico desenvolvido que apresenta na sua extremidade inferior um ressalto para a pança (Est. VI - fig. 1).

Esta forma apresenta afinidades com materiais provenientes de contextos habitacionais do Bronze Final da Beira Alta. Pode integrar o subtipo 4A de Canedotes, caracterizado como "recipientes com colo desenvolvido e convergente, por vezes bem marcado por uma chanfradura no arranque da pança e bordo extrovertido de lábio convexo ou convexo afilado" (Canha, 2002, 199). Aparece ainda em sítios do Alto Mondego [correspondendo ao tipo 45 de Senna-Martinez $(1993,102)$ ] ou na Senhora da Guia, integrando-se no tipo C1b de Armando Coelho Ferreira da Silva (1986, Est. XLII, 8) ${ }^{7}$. A norte está presente, por exemplo na Bouça do Frade - tipo 8 deste sítio (Jorge, 1988, 24). Na Beira Interior encontram-se no Monte do Frade (tipo 2) e na Moreirinha (tipo 2) (Vilaça, 1995, 153, 231). Propomos, portanto, uma cronologia dentro do Bronze Final para a camada 3. Por outro lado, as características técnicas dos restantes fragmentos não contrariam esta adscrição.

Quanto aos materiais provenientes da camada 2, parecem apresentar algumas diferenças em relação aos provenientes da camada que lhe subjaz, nomeadamente ao nível das cores e dos tratamentos de superfície. No entanto, julgamos que não será de valorizar estas diferenças enquanto indiciadoras de uma cronologia diferente. Em primeiro lugar, a amostra é demasiado diminuta para ser valorizada. Por outro lado, em relação às cores, como foi já escrito noutro sítio e por

7 A pança do fragmento deste sítio encontra-se, no entanto, decorada. 
outra autora, estas podem variar muito na mesma peça e ser consequência não só da matéria-prima utilizada, da temperatura atingida na temperatura e da "atmosfera criada", mas também da sua utilização e de "factores naturais decorrentes da sua deposição" (Vilaça, 1995, 48). Do mesmo modo, valorizar o excesso de mais 6 cacos polidos (quantos destes não pertencerão à mesma peça?!) numa camada parece-nos extremamente exagerado. Por outro lado, há que pensar o contexto em que se encontram: terão sido aí depositados quando da construção da mamoa ou são escorrências de materiais exumados em antigas violações e largados em cima do cairn? Somos, pois, forçados a seguir um raciocínio contrário ao que comummente se utiliza no discurso arqueológico: neste caso temos que procurar paralelos para a estrutura e datar o material e como vimos atrás aqueles são adscritos ao Bronze Médio e Final. Uma vez que a camada que se encontra sob o monumento foi inserida no segundo período referido, estas peças não poderão consequentemente ser anteriores.

A diferença dos conjuntos artefactuais, a ser valorizada, deve ser compreendida, por um lado como resultado da conformidade das peças em relação aos contextos a que se destinavam e, por outro, às condições de deposição e pós-deposição a que foram sujeitas. Isto é, se nos encontramos frente ao que resta de um acto de violação é porque estas peças foram feitas para serem depositadas num local específico e, certamente, obedeceriam a determinadas condicionantes daí advindas, sendo, de igual modo, influenciadas pelos rituais que envolveram essa mesma deposição (o fogo parece estar muito presente nestes rituais). As características com que nos chegam agora estão também condicionadas pela sua remoção e segunda deposição, agora em cima do cairn onde foram sujeitas a processos como os de escorrência por entre as pedras e os resultantes de contacto com sedimentos mais orgânicos. Da mesma forma, se nos encontramos frente a deposições intencionais efectuadas pelos construtores do monumento, as peças foram escolhidas, partidas e sujeitas a todos os processos pós-deposicionais referidos no caso anterior. Obviamente, existirão outras alternativas interpretativas. As que expusemos tiveram como único objectivo (por enquanto) a ilustração do que defendemos anteriormente. 


\section{Discussão}

Os monumentos associados a este período têm diversas tipologias e modelos de implantação a eles associados, mas caracterizam-se genericamente por corresponderem a construções de forma subcircular de pequenas dimensões, com ou sem tumulus, com pouco espólio associado. Os tumuli, quando associados a estes monumentos, são também eles de pequena volumetria. A pouca visibilidade destes monumentos é colmatada pela utilização de matérias-primas (destacando-se o quartzo) que lhes conferem algum destaque na paisagem. Temos como exemplos, entre outros, os tumuli já referidos do Pousadão, Senhora da Ouvida ou Fonte da Malga. Materiais mais antigos encontrados em contextos junto a estes monumentos não são comuns. Contudo, a proximidade destes com outros mais antigos é comum na Beira Alta (v. g. Fonte da Malga, Caramelo ou Mazugueira, ou Senhora da Ouvida). Um de nós defendeu já anteriormente a apropriação de sítios anteriores por parte das comunidades do Bronze Final, verificando-se tal fenómeno, tanto em necrópoles como na arte rupestre (Santos, 2003, 144-145).

No caso presente parece-nos que mais uma vez nos encontramos perante uma situação do mesmo tipo. Aqui, contudo, um contexto funerário parece ter-se seguido a um sítio de habitat do qual apenas resta o que ficou sob o monumento. A visualização desse "passado" poderá ter sido conseguida pela edificação das estruturas circulares anexas a ambos os monumentos. Deste modo, essas construções poderão representar a petrificação do Tempo. Em texto recente, um de nós já havia referido a importância simbólica de tal acto de materializar o Tempo. Como aí referimos, aquele pode ser encarado como uma das "realidades" mais aptas à construção de metáforas e analogias por parte de quem detém o poder e que deste modo o pretende manter (Santos, 2006, 59-62). Neste caso em concreto, à materialização do Tempo podemos juntar a sua própria manipulação, nomeadamente através da recontextualização da laje gravada. Como escrevemos atrás, temos razões para colocar a possibilidade desta não se encontrar no seu "contexto de origem"; a sua utilização num novo cenário poderá em si corresponder ao testemunho material da reconfiguração temporal e do conjunto de referências que constituem a "biografia" da própria laje. Ao admitirmos que a peça terá sido originalmente criada na primeira fase de ocupação do sítio, o que, metonimicamente, se encontra contido na peça é precisamente o sítio anterior... 
Frente às características físicas que unificam o tipo de monumentos que temos vindo a referir e que se encontram definidas acima, talvez seja de assumir cada vez mais a materialização e manipulação do Tempo e as reconfigurações do local (pelo menos, no caso que agora nos toca) por parte daquelas comunidades, processo esse que, desde logo, continua ainda hoje, ou não passou esta necrópole por um curto período em que foi sítio arqueológico? E não morreu enquanto troço da A24?...

\section{BIBLIOGRAFIA CITADA}

Bourdieu, P. (2002) - Esboço de uma teoria da prática - Precedido de Três Estudos de Etnologia Cabila, Celta Editora, Oeiras.

Canha, A. J. (1999) - "Canedotes (Vila Nova de Paiva, Viseu), povoado do Bronze Final. Notícia Preliminar das escavações do sector II", Estudos Pré-históricos, vol. VII, CEPBA, Viseu, pp. 281-291.

Canha, A. J. (2002) - Canedotes - Povoado do Bronze Final do Alto Paiva, Faculdade de Letras da Universidade do Porto, Porto (dissertação de mestrado, policopiada).

Cortez, F. R. (1951) - "Das populações pré-celtas do Norte de Portugal", Boletim da Associação de Filosofia Natural, vol. II, n. ${ }^{\circ} 21$, Porto, pp. 159-184.

Costa, J. C.; Aguiar, C.; Capelo, J. H.; Lousã, M.; Neto, C. (1998) - Biogeografia de Portugal Continental, Associação Lusitana de Fitossociologia (ALFA), Bragança ["Quercetea", vol. 0].

Cruz, D. J. da (1995) - "Cronologia dos monumentos com tumulus do Noroeste Peninsular e da Beira Alta", Estudos Pré-históricos, vol. III, CEPBA, Viseu, pp. 81-119 .

CRUZ, D. J. da (1998) - "Expressões funerárias e cultuais no Norte da Beira Alta (V II milénios a. C.)", Actas do Colóquio "A Pré-história na Beira Interior" (Tondela, Nov. 1997), CEPBA, Viseu, pp. 149-166 [Estudos Pré-históricos, vol. VI].

Cruz, D. J. da (2001) - O Alto Paiva: Megalitismo, diversidade tumular e práticas rituais durante a Pré-história recente, 2 volumes, FLUC, Coimbra (dissertação de doutoramento, policopiada).

Cruz, D. J.; Gomes, L. F. C.; Carvalho, P. M. S. (1998a) - "Monumento 2 da Serra da Muna (Campo, Viseu). Resultados preliminares dos trabalhos de escavação", Estudos Pré-históricos, vol. VI (Actas do Colóquio "A Pré-História na Beira Interior", Tondela), CEPBA, Viseu, pp. 375-395.

Cruz, D. J.; Gomes, L. F. C.; Carvalho, P. M. S. (1998b) - "O grupo de tumuli da Casinha Derribada (concelho de Viseu). Resultados preliminares da escavação arqueológica dos monumentos 3, 4 e 5", Conimbriga, 37, IAFLUC, Coimbra, pp. 5-76.

Cruz, D. J.; VIlaÇA, R. (1999) - "O grupo de tumuli da "Senhora da Ouvida" (Monteiras/Moura Morta, Castro Daire, Viseu) Resultados dos trabalhos arqueológicos", 
Estudos Pré-históricos, vol. VII, Centro de Estudos Pré-históricos da Beira Alta, Viseu, pp. 129-161.

Cruz, D. J; Vilaça, R.; Santos, A. T.; Marques, J. N. (2000) - "O grupo de tumuli do Pousadão (Vila Nova de Paiva, Viseu)”, Estudos Pré-históricos, vol. VIII, Centro de Estudos Pré-históricos da Beira Alta, Viseu, pp. 125-150.

Daveau, S. (1997) - "Os tipos climáticos”, in Ribeiro, O., LAUTEnSACH, H., Geografia de Portugal, vol. II, Edições Sá da Costa, Lisboa [ $3^{\mathrm{a}}$ edição].

ECO, U. (1990) - Os Limites da Interpretação, Difel, Lisboa.

Ferreira, A. B. (1978) - Planaltos e montanhas do Norte da Beira - Estudos de Geomorfologia [Memórias do Centro de Estudos Geográficos, n. ${ }^{\circ} 4$ ], Lisboa.

Gomes, I. (2000-2001) - "Estudo do material lítico do Crasto de Palheiros - Murça. Uma primeira proposta metodológica - 1. parte", Portugália, nova série, vol. XXI-XXII, DCTP-FLUP, Porto, pp. 41-101.

Heidegger, M. (1998) - El Ser y el Tiempo, Fondo de Cultura Económica, Madrid. Jorge, S. O. (1988) - O povoado da Bouça do Frade (Baião) no quadro do Bronze Final do Norte de Portugal, GEAP, Porto, [Monografias Arqueológicas, 2].

KALB, P. (1994) - "Reflexões sobre a utilização de necrópoles megalíticas na Idade do Bronze", Estudos Pré-históricos, vol. II (Actas do Seminário "O Megalitismo no Centro de Portugal”, Mangualde, Nov. 1992), CEPBA, Viseu, pp. 415-426.

KALb, P.; HöcK, M. (1979) - "Escavações na necrópole de mamoas "Fonte da Malga" - Viseu, Portugal”, Beira Alta, XXXVIII (3), Viseu, pp. 593-604.

López Sáez, J. A.; López García, P.; Cruz, D. J.; Canha, A. J. (2000) - "Paleovegetação e impacto humano durante a Pré-história recente na região do Alto Paiva: Palinologia do povoado do Bronze Final de Canedotes (Vila Nova de Paiva, Viseu), Estudos Pré-históricos, vol. VIII, CEPBA, Viseu, pp. 161-185.

Loureiro, S.; MArques, J. N. (2006) - “O Alto Paiva: A ocupação humana no I. ${ }^{\circ}$ milénio A. C.", Conimbriga, vol. XLV, IAFLUC, Coimbra, pp. 105-123.

Loureiro, S.; Valinho, A. (2000) - "O Castro de Vila Cova-à-Coelheira na Idade do Ferro do Alto Paiva - Resultados preliminares", Actas do III Congresso de Arqueologia Peninsular, vol. 5, ADECAP, Porto, pp. 495-505.

RAPOPORT, A. (1994) - "Spatial organization and the built environment", Companion Encyclopedia of Anthropology, editado por T. Ingold, Routledge, Londres e Nova Iorque, pp. 460-502.

Rodrigues, J. B.; Silva, C. T. da; Almeida, D.; VAZ, J. L. I. (1989) - “A Pedra dos Pratos”, Actas do I Colóquio Arqueológico de Viseu, Viseu, pp. 275-281.

Santos, A. T. (2000) - "A Pedra dos Pratos (Covelo de Paiva, Moledo, Castro Daire, Viseu). Breve estudo interpretativo”, Estudos Pré-históricos, vol. VIII, CEPBA, Viseu, pp. 113-124.

SAntos, A. T. (2003) - Uma abordagem Hermenêutica-Fenomenológica à arte rupestre da Beira Alta. O caso do Fial (Tondela, Viseu), Faculdade de Letras da Universidade do Porto, Porto (dissertação de mestrado, policopiada).

SAntos, A. T. (2006) - "A arte rupestre na Proto-história Antiga do Vale de Besteiros: interpretação e territorialidade”, Conimbriga, vol. XLV, IAFLUC, Coimbra, 47$-64$. 
Santos, A. T.; Aveleira, A. (2001) - "A necrópole de "Caramelo - Mazugueira" (Caparrosa, Tondela, Viseu)", Estudos Pré-históricos, vol. IX, CEPBA, Viseu, pp. 123-131.

SChermerhorn, L. J. G. (1980) - Carta Geológica de Portugal na escala 1/50.000. Notícia esplicativa da folha 14-C. Castro Daire, Serviços Geológicos de Portugal, Lisboa.

SEnNA-Martinez, J. C. (1993) - “O grupo Baiões/Santa Luzia: Contribuições para uma tipologia da olaria", Trabalhos de Arqueologia da E. A. M., 1, Colibri, Lisboa, pp. 93-123.

Silva, A. C. F. (1986) - A cultura castreja no Noroeste de Portugal, Museu Arqueológico da Citânia de Sanfins, Paços de Ferreira.

SILvA, C. T. da (1978) - "Gravuras rupestres inéditas da Beira Alta", Actas das III Jornadas Arqueológicas, Associação dos Arqueólogos Portugueses, Lisboa, pp. 167$-196$.

SILVA, C. T. da (1985) - "A arte rupestre da região do Vouga e a problemática da sua cronologia”, Conferência Internacional Os Portugueses e o Mundo, Porto, 1985, pp. 179-197.

Thomas, J. (1996) - Time, Culture and Identity - An interpretive archaeology, Routledge, London and New York.

TiLley, C. (1999) - Metaphor and Material Culture, Blackwell Publishers, Massachusetts.

VAlinho, A.; Loureiro, S. (1999) - "O Castro de Vila Cova-à-Coelheira (Vila Nova de Paiva, Viseu), Estudos Pré-históricos, vol. VII, CEPBA, Viseu, pp. 293-300.

VALERA, A. C. (2000) - "Pensar o Tempo: Critérios para uma periodização da Pré-história recente da bacia interior do Mondego", Pré-história Recente da Península Ibérica, ADECAP, Porto, pp. 147-160 [Actas do 3. ${ }^{\circ}$ Congresso de Arqueologia Peninsular, vol. IV].

VILAÇA, R. (1995) - Aspectos do povoamento da Beira Interior (Centro e Sul) nos finais da Idade do Bronze, 2 volumes, IPPAR, Lisboa [Trabalhos de Arqueologia, 9].

VILAÇA, R.; CruZ, D. J. (1995) - "Canedotes (Vila Nova de Paiva, Viseu). Povoado pré-histórico do Bronze Final”, Estudos Pré-históricos, vol. III, CEPBA, Viseu, pp. 225-261.

VILAÇA, R.; CRuZ, D. J. (1999) - "Práticas funerárias e cultuais dos finais da Idade Bronze na Beira Alta", Arqueologia, 24, GEAP, Porto, pp. 73-99. 
EsT. I

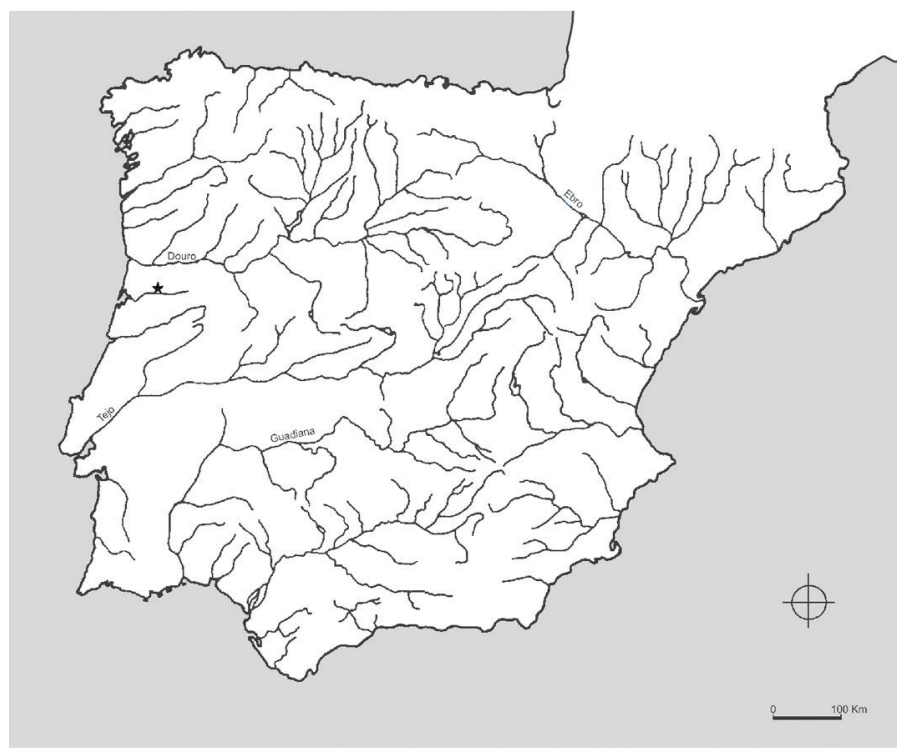

FIG. 1 - Localização da necrópole na Península Ibérica (adaptado a partir de Vilaça, 1995, Est. I).

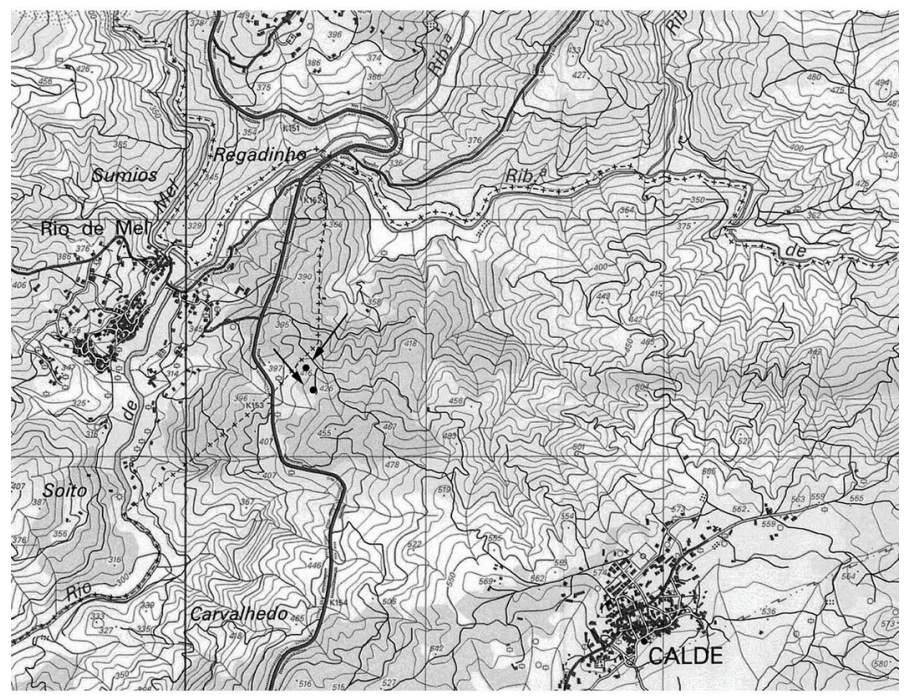

FIG. 2 - Localização da necrópole na Carta Militar de Portugal, escala 1:25 000, fl. 167. 
EsT. II

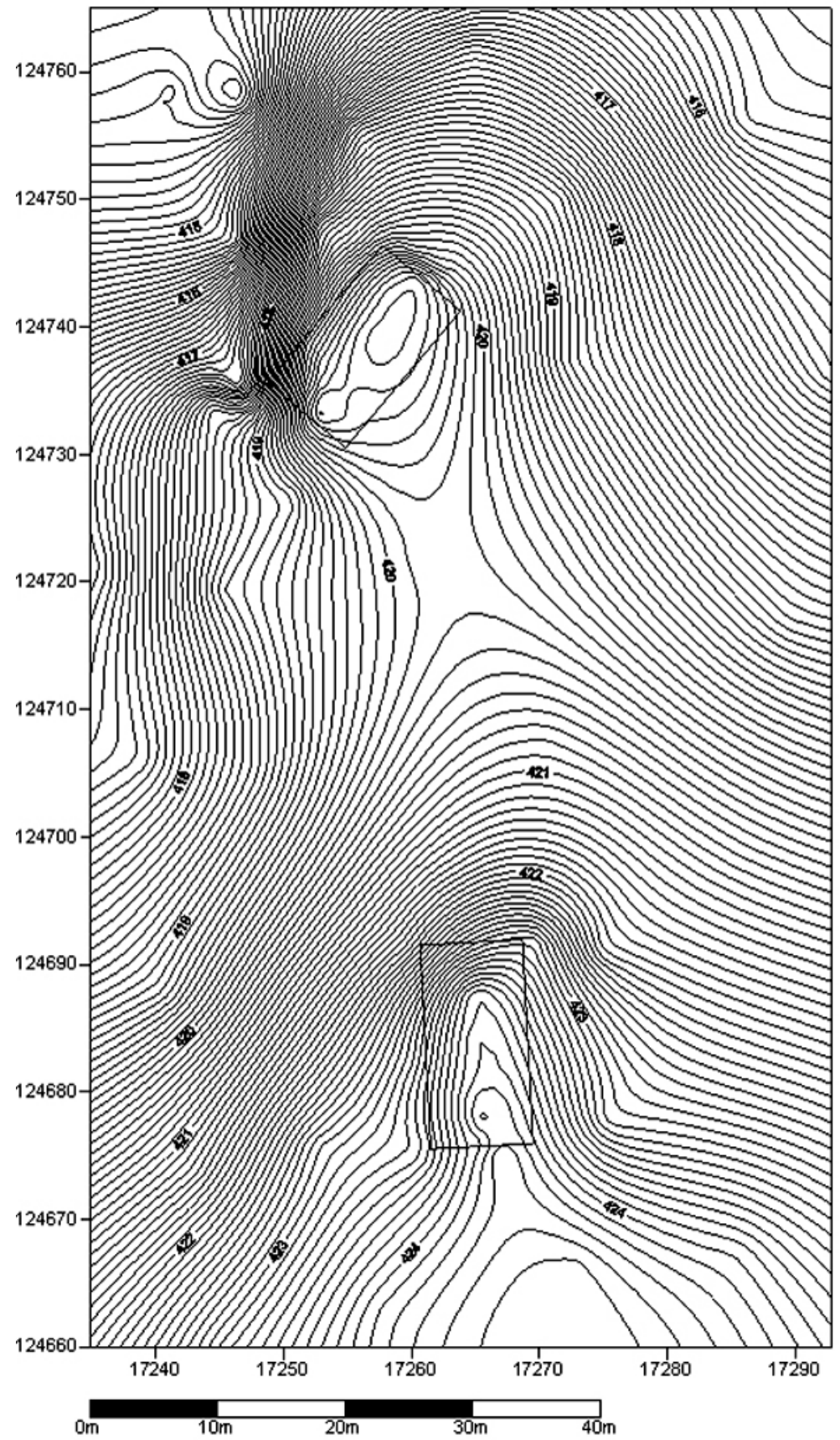

N 
EST. III

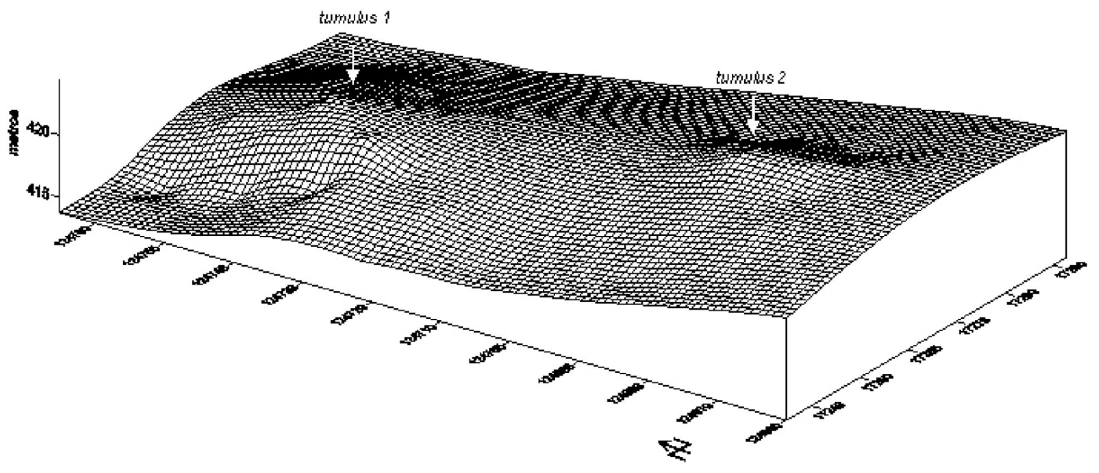

FIG. 1 - Vista tridimensional da necrópole.

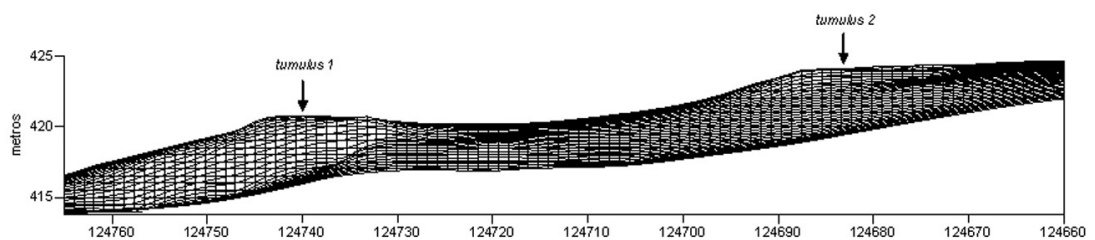

FIG. 2 - Perspectiva dos monumentos ao longo dos 105 m topografados da linha de festo da encosta (direcção norte-sul). 


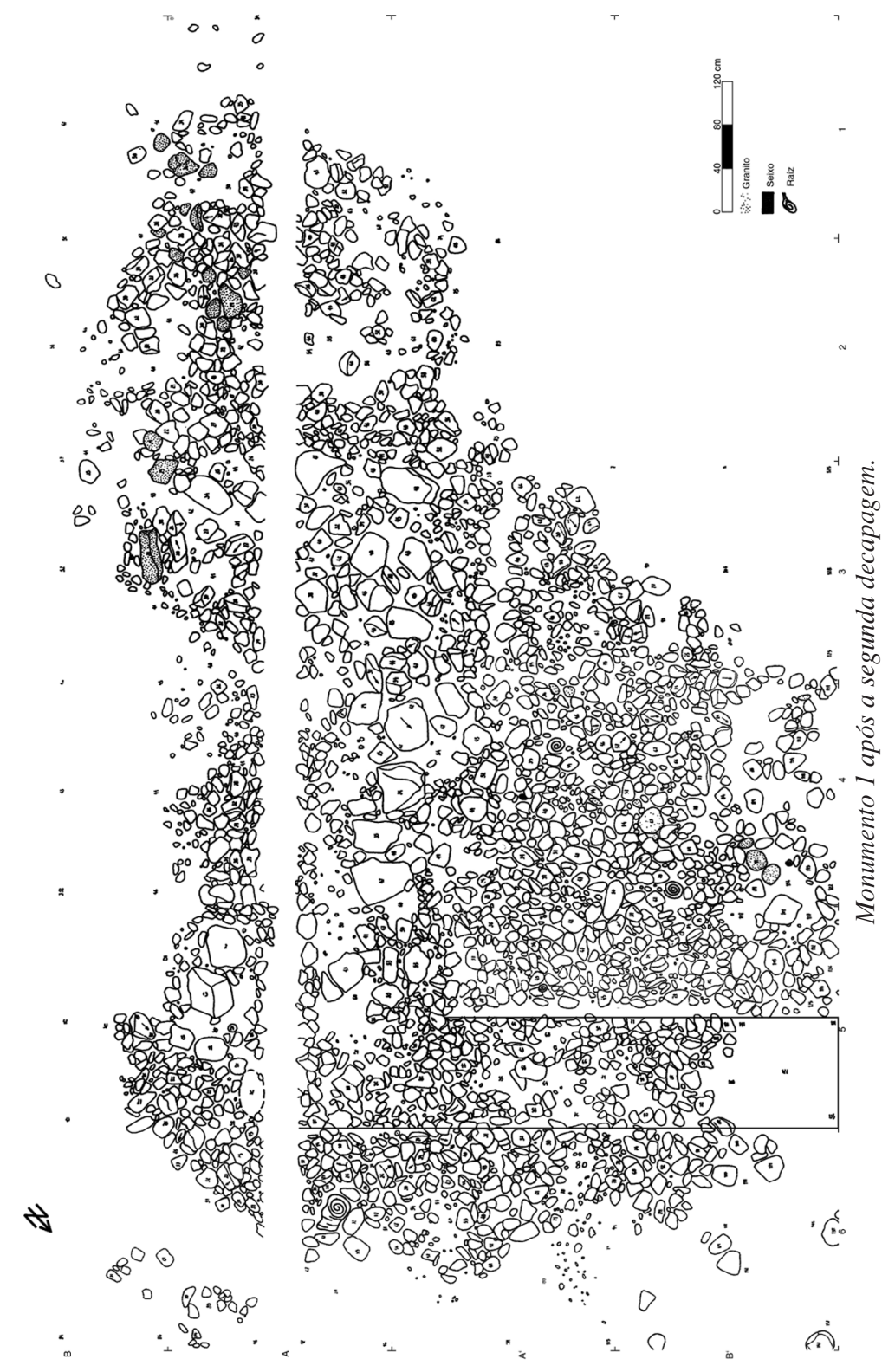


Est. V

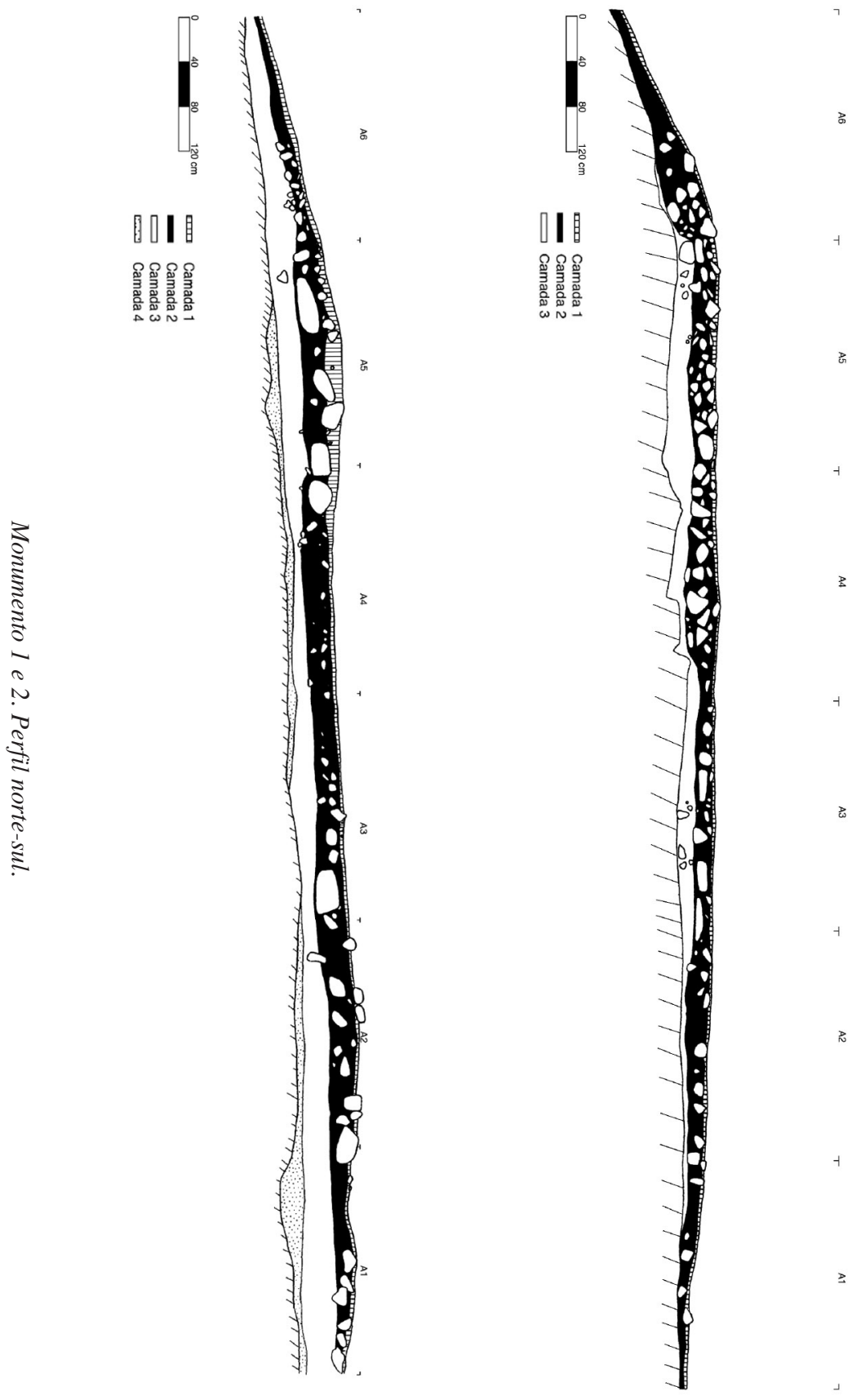




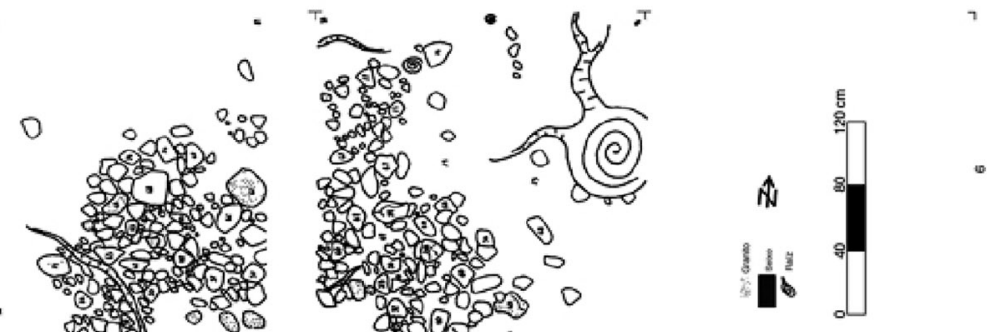

+ f8\%

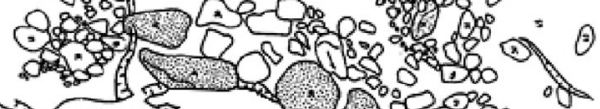
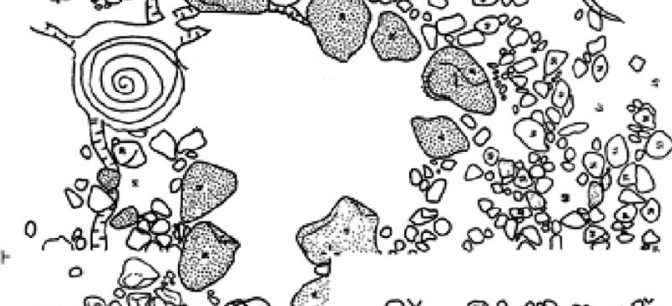

- 0 s

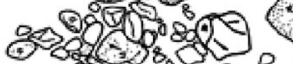

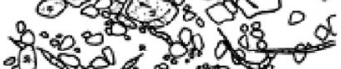

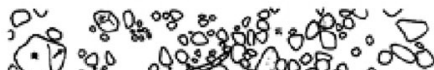

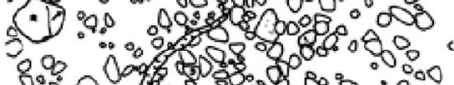

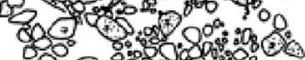

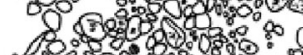

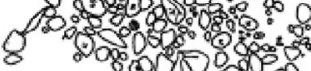

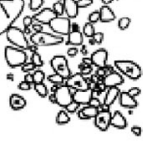

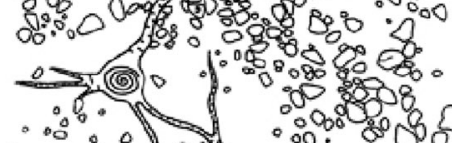
$\because \therefore \circ$ a $\because 00$ of $0: 00 \% 08$ \% 8.0 " की

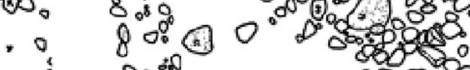

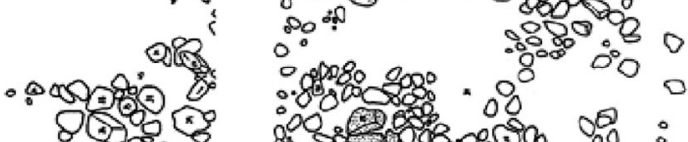

$\hat{N}$

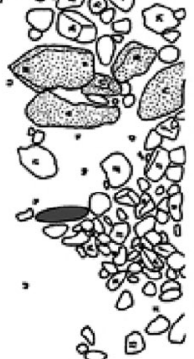

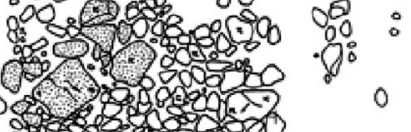

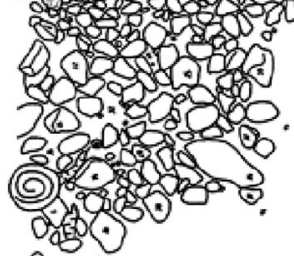


EST. VII
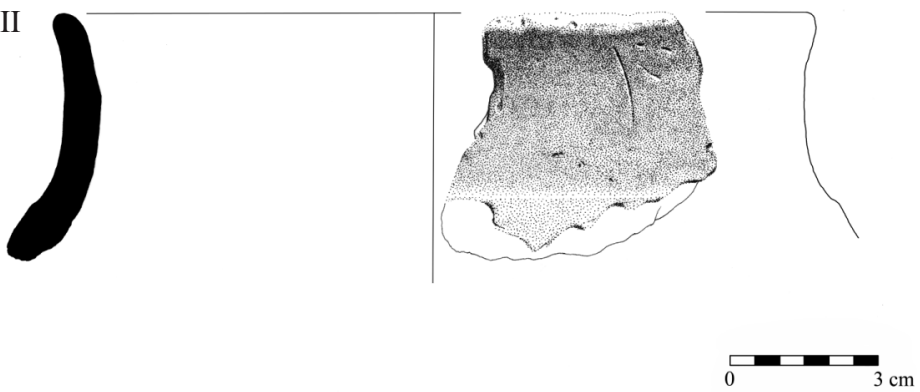

FIG. 1 - Material cerâmico proveniente do Monumento 2.
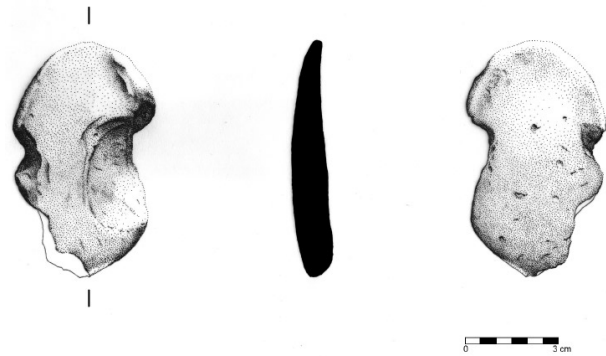

FIG. 2 - Peso proveniente do Monumento 2.

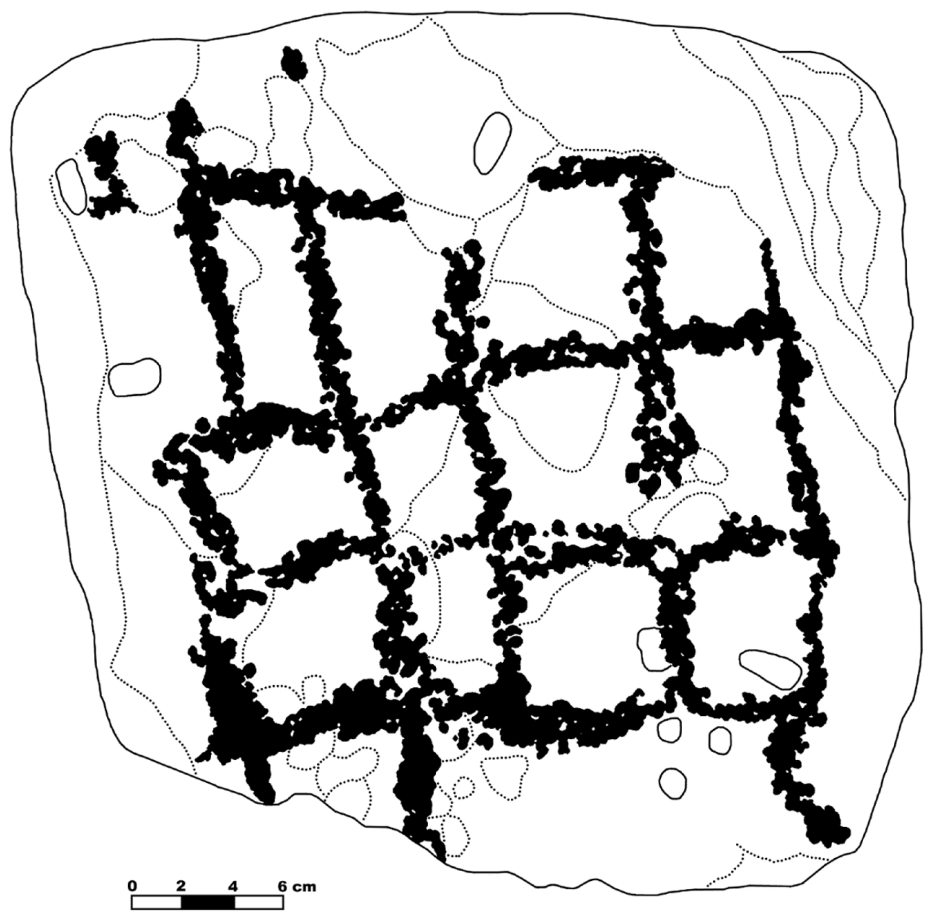

FIG. 3 - Laje gravada do Monumento 2. 


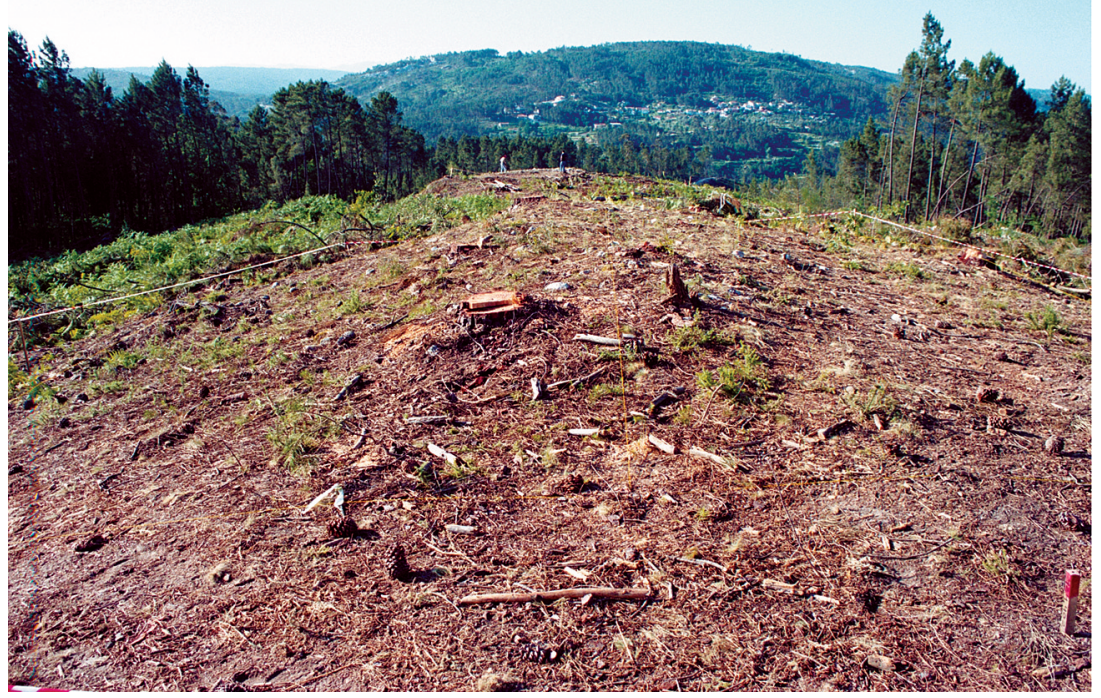

Fото 1 - Vista geral dos monumentos após a remoção da vegetação. Em primeiro plano observa-se o monumento 2 e, ao fundo, o monumento 1.

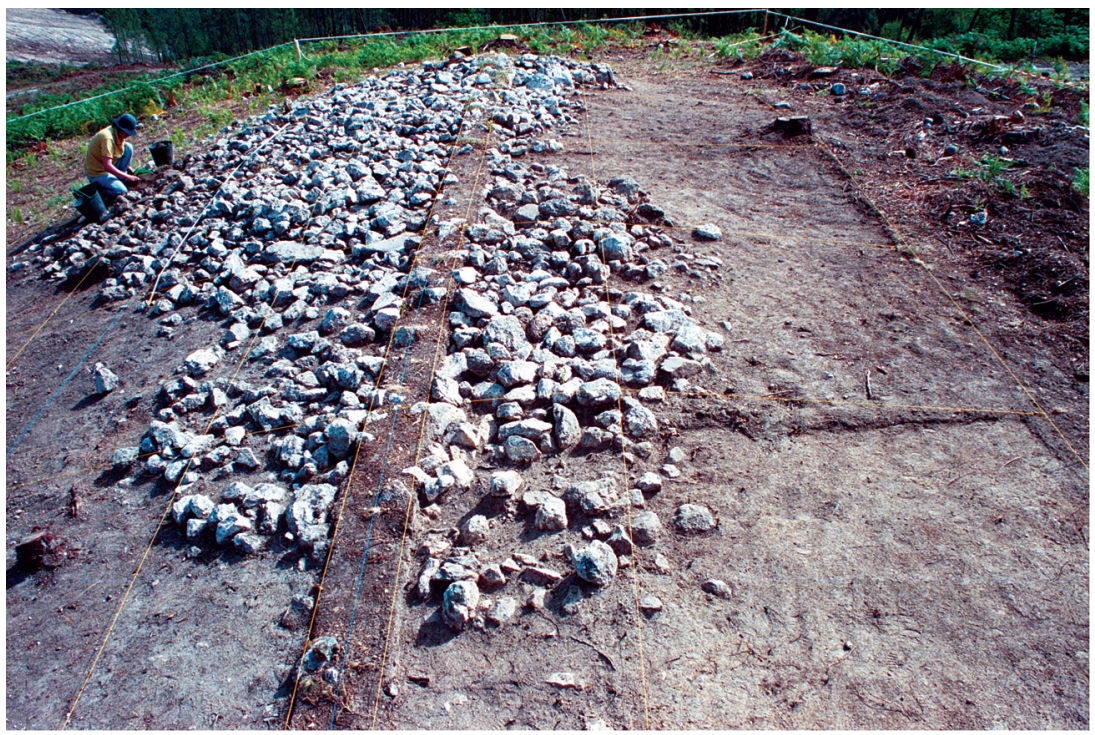

Fото 2 - O monumento 1 após a primeira decapagem. Vista de sudoeste. 


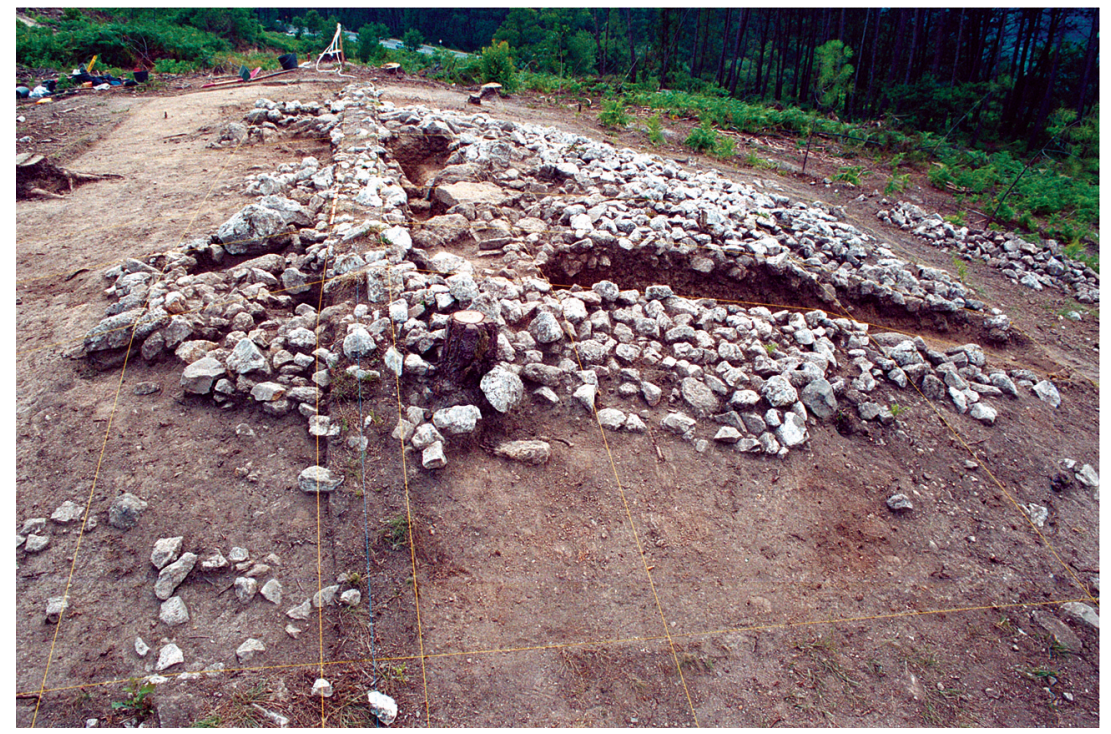

Fото 3 - O monumento 1 após a primeira decapagem. Vista de nordeste. Em primeiro plano, à direita, observa-se o corte efectuado no tumulus.

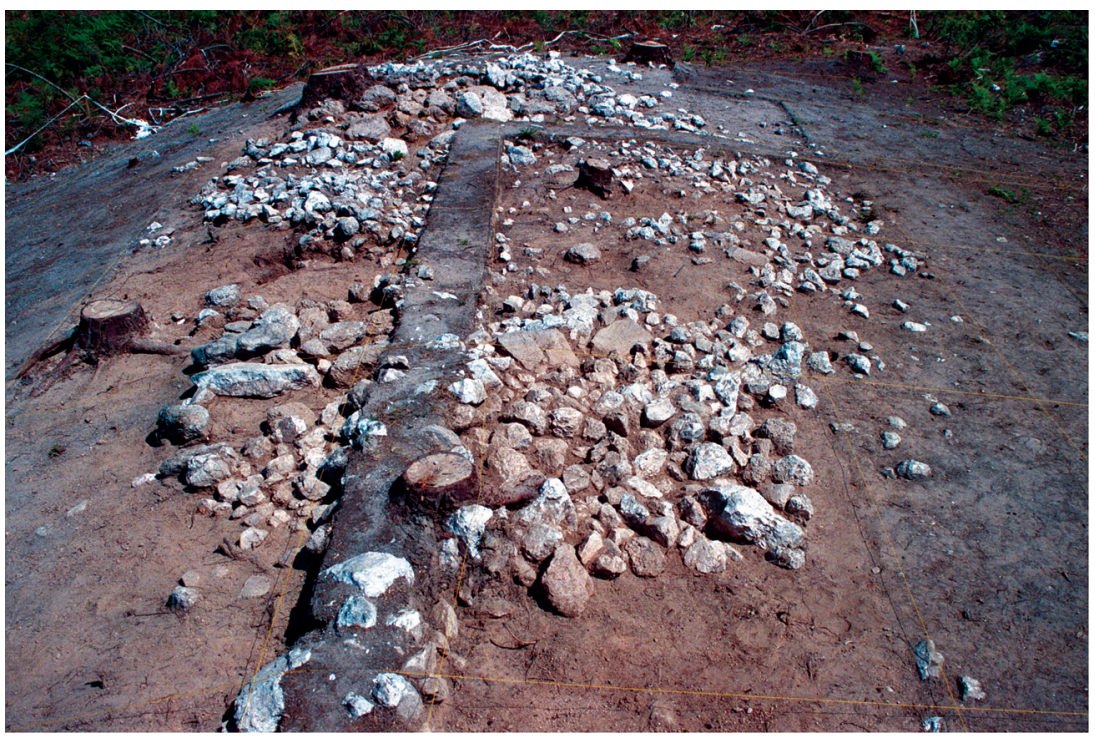

Fото 4 - O monumento 2 após a segunda decapagem. Vista de sul. 


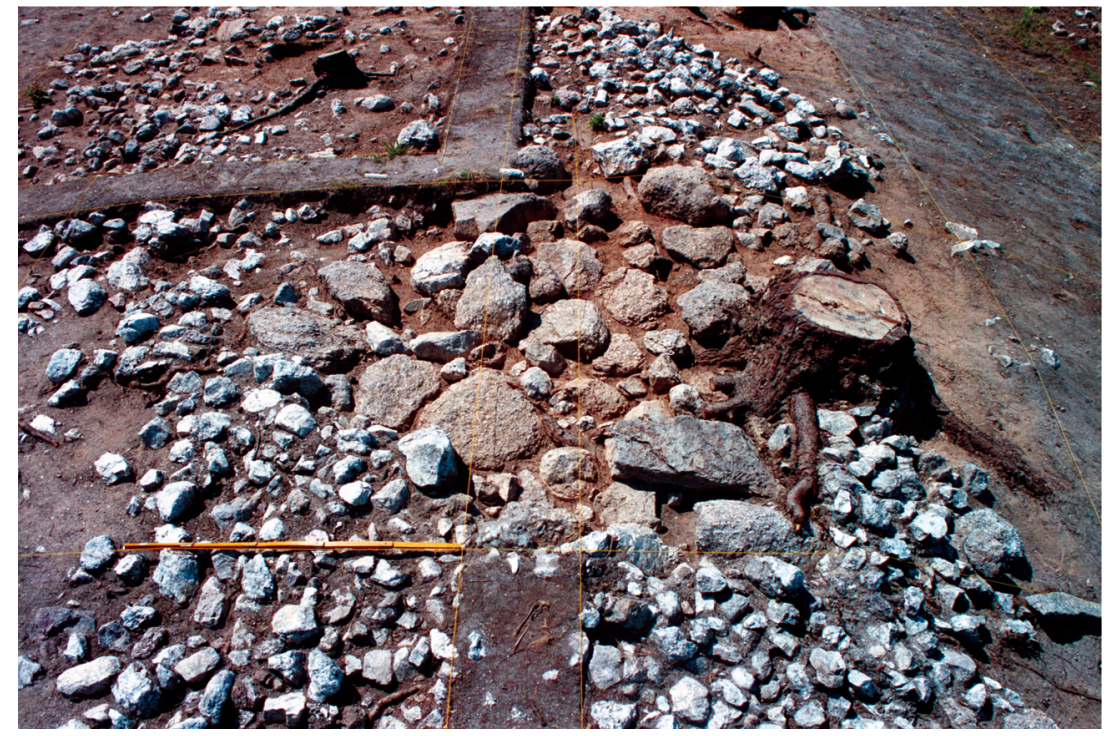

Fото 5 - A área central do monumento 2. Vista de norte.

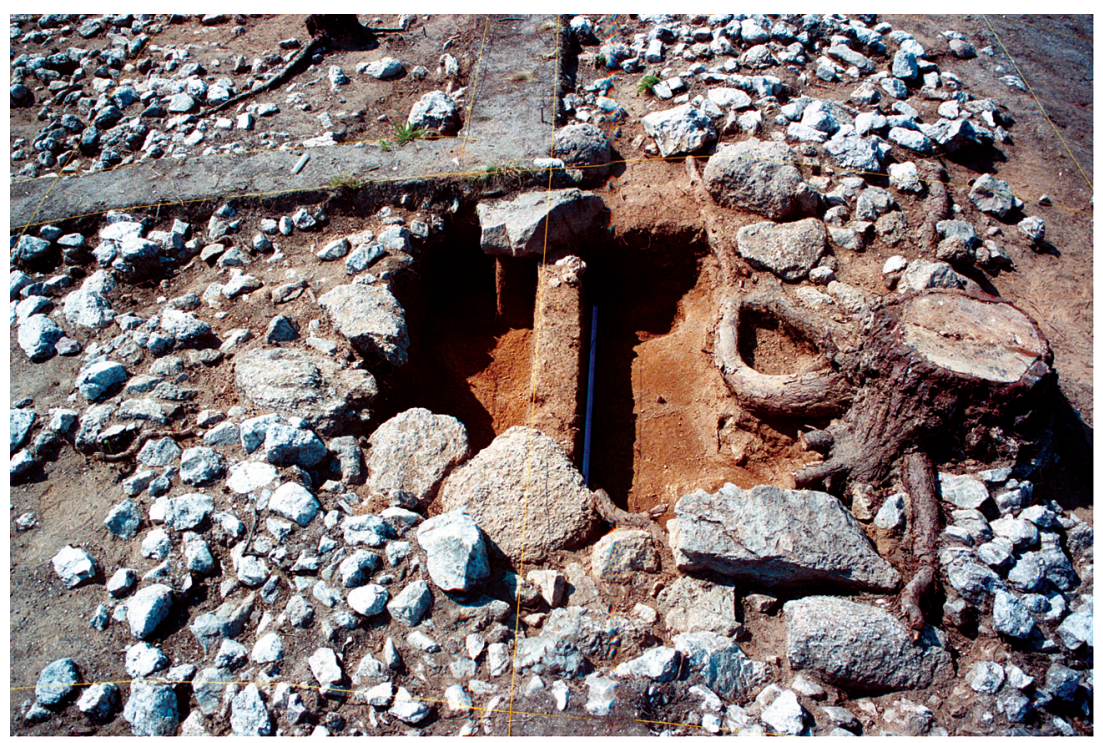

Fото 6 - Escavação da área central do monumento 2. Vista de norte. 


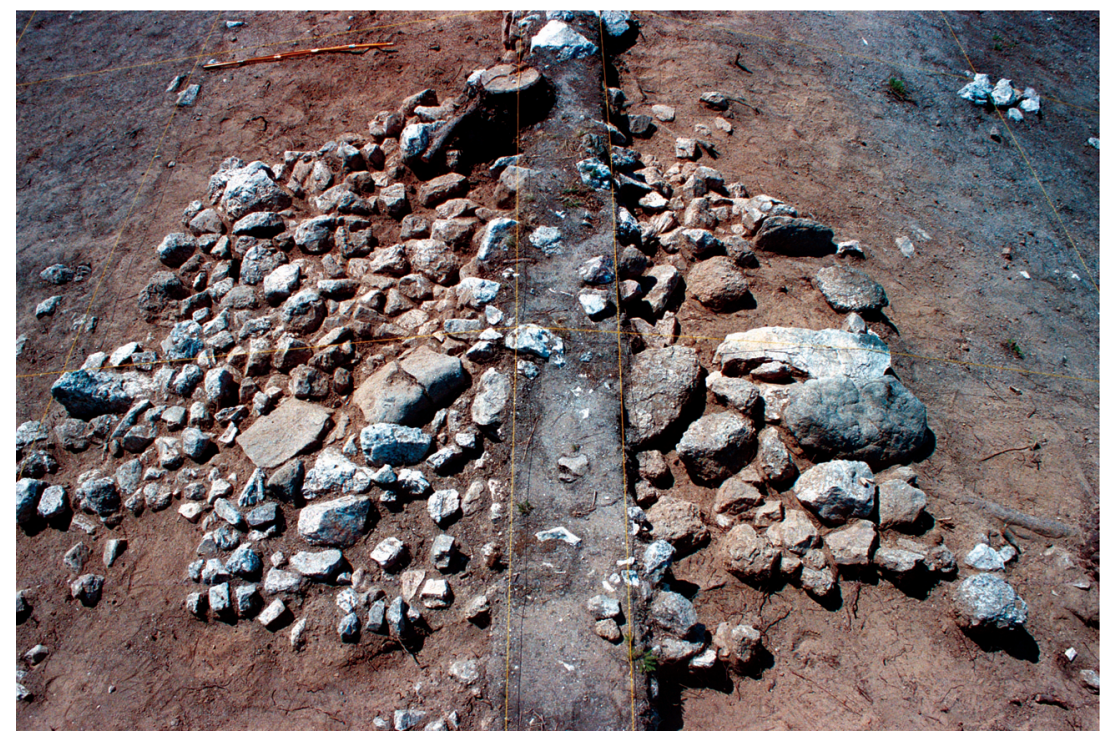

Fото 7 - Estrutura periférica do monumento 2 e "condenação" da estrutura mais antiga. Vista de norte.

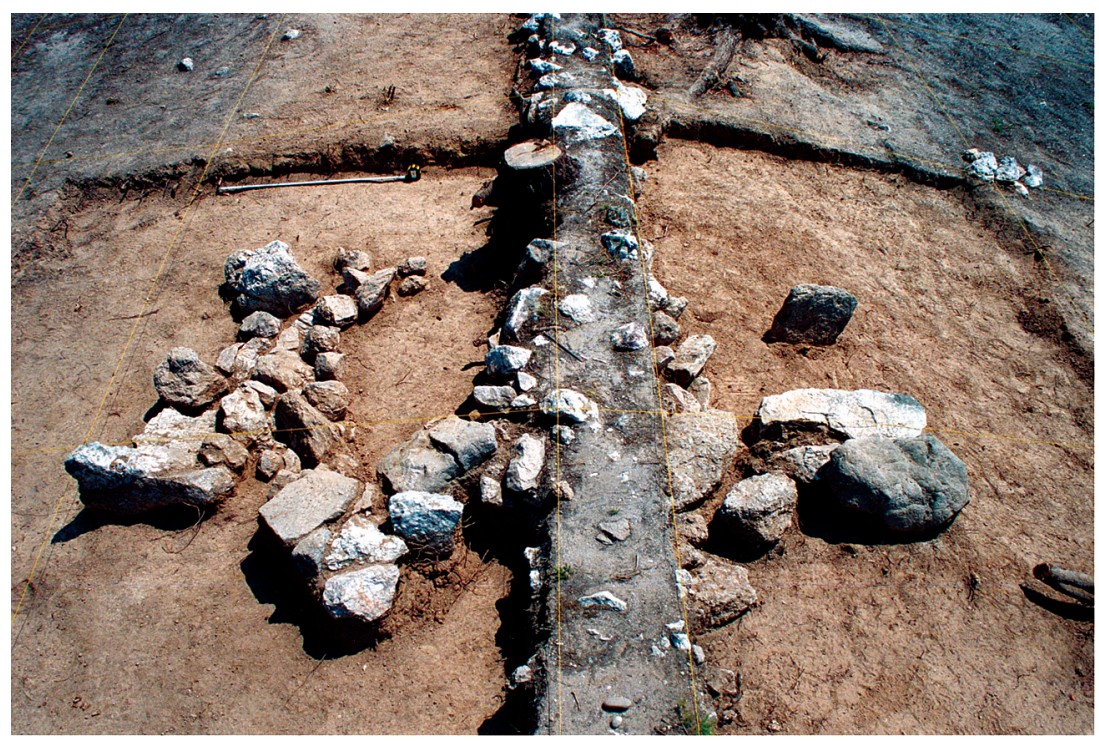

Fото 8 - Monumento 2. Em primeiro plano observa-se a estrutura mais antiga. Atrás, à direita, observa-se a estrutura periférica do monumento, e ao centro, a laje gravada. Vista de este. 